\title{
TAXING CORPORATE REORGANIZATIONS: PURGING PENELOPE'S WEB
}

\author{
DANIEL Q. PosIN ${ }^{\dagger}$
}

Table of Contents

InTRODUCTION ....................... 1336

I. Corporate - Reorganizations as Dispositions of Property . . . . . . . . . . . . . . . . . . . . 1337

II. History of Corporate Reorganizations . . . . . 1340

A. Early Stirrings ..................... 1340

B. Statutory Development ................ 1348

C. The Judicial Doctrines................. 1353

1. Continuity of Interest $\ldots \ldots \ldots \ldots \ldots \ldots \ldots \ldots$

a. Historical Development............ 1353

b. Current Issues ................ 1362

i. Required Period of Continuity .... 1362

ii. Arbitrage ............... 1364

iii. Use of the Parent's Stock-The Groman Doctrine ........... 1369

c. Critique ................... 1371

d. Recent Development: The Paulsen Case 1374

2. Substance over Form ............... 1378

III. Overview of Gurrent Law............... 1381

A. Definition of Acquisitive Reorganizations...... 1382

1. The Type A Reorganization........... 1382

2. The Type B Reorganization........... 1383

3. The Type C Reorganization........... 1383

4. The Forward Triangular Type A Reorganization ..................... 1385

5. The Reverse Triangular Type A Reorganization .......................... 1385

B. Overlap Problems ................... 1386

† Associate Professor of Law, Southern Methodist University. B.A. 1963, University of California, Berkeley; M.A., J.D. 1967, Yale University; LL.M. 1975, New York University.

I would like to express my appreciation to Alan R. Bromberg, University Distinguished Professor of Law, Southern Methodist University, for his interest in this work. 
C. Treatment of Corporations ............ 1387

D. Treatment of Shareholders ............. 1388

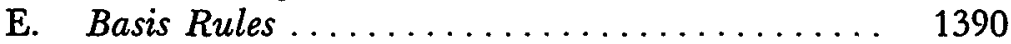

F. Carryover of Tax Attributes ............ 1390

IV. Senate Finance Committee Staff Proposals for REFORM . . . . . . . . . . . . . . . . . . . 1391

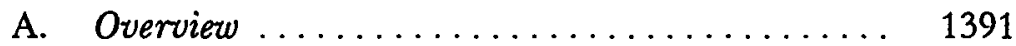

1. Qualified Acquisition............... 1392

a. Carryover Basis Acquisitions ........ 1392

i. Qualified Asset Acquisitions ...... 1393

ii. Qualified Stock Acquisitions...... 1393

b. Cost Basis Acquisitions ............ 1394

2. Shareholder Treatment .............. 1395

B. Criticism ......................... 1395

1. Complexity . . . . . . . . . . . . . . . . 1395

2. An Election in Tax Polarity........... 1397

3. Selective Asset Sales ................ 1400

4. Entity Versus Aggregàte . . . . . . . . . . . 1402

5. Continuity of Interest ............... 1403

6. Unforeseen Practitioner Ingenuity ........ 1404

7. Transition..................... 1405

Conclusion . . . . . . . . . . . . . . . 1405

No cure for law but more law.

-Llewellyn, The Bramble Bush

\section{INTRODUCTION}

Criticism of the laws governing corporate reorganization is not a new phenomenon. Over forty years ago, a leading commentator noted that

[t]here are three striking things about the reorganization sections of the federal income tax law. The first is their almost unbelievable intricacy. The second is that due to this very intricacy, they have been ... one of the most serious tax avoidance leaks . . . . But the most striking thing of all is that no one can satisfactorily explain why they were ever enacted or why, having been enacted, they have remained. ${ }^{1}$

1 Sandberg, The Income Tax Subsidy to "Reorganizations," 38 Colum. L. Rev. 98, 98 (1938); see also H.R. REP. No. 704, 73d Cong., 2d Sess. 12-14 (1934), re- 
This view was offered in 1938, and many would say that matters have deteriorated since then. ${ }^{2}$

Provisions similar to those under criticism have remained in place down to the present day. Over time, modern approaches have become entwined with older principles, creating a Penelope's web of legislative, judicial, and administrative rules, principles, and doctrines. Indeed, one commentator recently opined that the complexity of the corporate tax law is so great that it approaches that of living organisms, ${ }^{3}$ and that the perspective of a cultural anthropologist might successfully be employed for its study.

This Article takes a leaf from that book in exploring the evolution of the law of taxation of corporate acquisitions. After reviewing the historical development of reorganizations, the Article discusses the recent Supreme Court case of Paulsen $v$. Commissioner, ${ }^{5}$ which may give birth to a whole new species. It then examines the current problems of the organism and, with the perspective gained from that analysis, criticizes the Senate Finance Committee staff proposals for reform, which are derived from proposals of the American Law Institute and other professional associations. The Article concludes that, as with any complex biological organism, it is dangerous to introduce major mutations. ${ }^{6}$ The present system, flawed as it is, is preferable to the proposals for reform.

\section{Corporate Reorganizations as Dispositions of Property}

This Article focuses on five major types of acquisitive corporate

printed in 1939-1 C.B. 554, 563-65 (House Ways and Means Committee report proposing restrictions on the reorganization provisions of the tax code in order to prevent tax avoidance); S. REP. No. 558, 73d Cong., 2d Sess. 16-17 (1934), reprinted in 19391 C.B. 586, 598-99 (Senate Finance Committee expressing agreement with proposals aimed at eliminating tax-avoidance schemes).

2 See, e.g., Ginsburg, Tax Simplification-A Practitioner's View, 26 NAT'L TAx J. 317, 327-28 (1973); Roberts, A Report on Complexity and the Income Tax, 27 TAX L. REv. 325, 334 (1972).

3 See Clark, The Morphogenesis of Subchapter C: An Essay in Statutory Evolution and Reform, 87 YALE L.J. 90, 93 (1977).

- See id. at 90-91.

s 105 S. Ct. 627 (1985).

- The pioneering work of Dr. Hermann J. Muller showed that random X rays produced unfavorable mutations in the Drosophila melanogaster species of the fruit fly, including vermilion eyes, tan body, tiny bristles, truncated wings, splotched appearance, and cloven thorax. See Muller, The Problem of Genic Modification, 1928 ZEITSCHRIFT FUR INDUKTtVe Abstammungs-und Vererbungslehre 234 (Supp. 1) (Proceedings of the Fifth International Congress of Genetics, Berlin 1927), reprinted in $\mathrm{H}$. Muller, Studies in Genetics 252, 259-60 (1962). For this work Dr. Muller received the Nobel prize for medicine in 1946. See E. Garlson, Genes, Radiation, and Society: The Life and Work of H. J. Muller 308-13 (1981). 
reorganizations: Type A, a statutory merger or consolidation; Type B, a stock-for-stock acquisition; Type $\mathrm{C}$, an asset acquisition (sometimes called a practical merger); triangular Type A, a transaction involving a transfer of assets by the acquired corporation to the acquiring corporation's controlled subsidiary in exchange for stock of the parent; and reverse triangular Type $\mathrm{A}$, a transaction in which the acquiring corporation merges into the acquired corporation and the parent of the acquiring corporation then assumes control of the acquired corporation. ${ }^{7}$ Acquisitive reorganizations are part of the larger subject of corporate reorganizations; indeed, they form the lion's share of the law in this area. Since acquisitive transactions have been linked by statute, if not by economic reality, to the other forms of reorganization, much of what is said in this Article will apply to all forms of corporate reorganization. ${ }^{\mathbf{8}}$

The reorganizations discussed in this Article should be seen as a part of the broad category of transactions of sales and other dispositions of property. Indeed, the reorganization provisions were originally enacted as part of the same statutory scheme that provided for nonrecognition of like-kind exchanges and involuntary conversions. ${ }^{\circ}$ It is, therefore, useful to review briefly the basic rules for taxing dispositions of property, particularly as they relate to corporate reorganizations.

The first fundamental question in the taxation of corporate reorganization transactions is whether there has been a realizing event. In the American tax system, appreciation in the value of property is usually taxed only when the gain is realized, that is, when the property is sold or otherwise disposed of. ${ }^{10}$

7 Other types of reorganization, covered only incidentally in this Article, include Type $\mathrm{D}$, which involves either a shift of control or a corporate division; Type $\mathrm{E}$, a recapitalization or reshuffling of the capital structure of a single corporation; Type F, a mere change in identity, form, or place of organization of one corporation; and Type $G$, an acquisition of the assets of a corporation involved in a bankruptcy proceeding. See I.R.C. $\S 368(a)(1)(D)-(G)$ (1982 \& West Supp. 1985). Also not covered in this Article, except incidentally, are I.R.C. $\$ 351$ (1982), governing the transfer of property to a controlled corporation, and I.R.C. $\$ \S 331-346$ (1982 \& West Supp. 1985), governing corporate liquidations, although some of the goals sought to be accomplished through reorganizations can be achieved through these other transactions.

${ }^{8}$ See infra text accompanying notes 279-300.

- See Revenue Act of 1924, ch. 234, § 203, 43 Stat. 253, 256.

10 See Eisner v. Macomber, 252 U.S. 189, 202-03 (1920) (involving the taxability of a pro rata stock dividend, the treatment of which is currently governed by I.R.C. $\S 305$ (1982)); see also Marr v. United States, 268 U.S. 536 (1924) (holding that General Motors' change of state of incorporation from New Jersey to Delaware was a realization event). There are, however, exceptions to the requirement of realization. Among these are the undistributed profits of a controlled foreign corporation, a pro rata share of which is considered taxable income to United States shareholders, see I.R.C. $\S 951$ (a)(1) (1982), and commodity and stock option tax straddles, see I.R.C. $\S 1256$ 
This requirement of a realization is at the core of the field of corporate reorganizations. ${ }^{11}$ It is only because of the requirement of a realization that a significant amount of untaxed gain may accrue on stock or business assets. ${ }^{12}$ When a sale or other transaction involving a corporation occurs, this hitherto accrued and untaxed gain may be taxed unless the tax adviser plans for compliance with the complex rules governing nonrecognition of income. ${ }^{13}$

Once it is ascertained that there has been a realizing event (and usually that question is clear), the next issue is the size of the gain or loss realized. ${ }^{14}$ A shareholder disposing of stock, or a corporation disposing of assets in connection with a reorganization, must compute realized gain or loss. This computation is performed just as it would be for any taxpayer disposing of property: the gain or loss realized equals the amount realized minus the adjusted basis. ${ }^{16}$ The amount realized is the amount of money received plus the fair market value of any other property received. ${ }^{16}$ The adjusted basis is usually the cost of the property. If the property was acquired not by purchase but rather by gift, inheritance, or some other nonrecognition transaction, however, the basis of the property will be determined by the basis rule appropriate to that transaction. Moreover, the basis may be adjusted for such items as depreciation, capital expenditures, or casualty losses. ${ }^{17}$

After the amount of gain or loss "realized" has been computed, attention then focuses on the amount of gain or loss that will be "recognized." Income realized in an acquisitive corporate transaction will receive nonrecognition treatment-with an appropriate adjustment to basis-when the transaction is characterized as a "reorganization" and the parties follow certain further rules set forth in the Code. ${ }^{18}$

The final task is characterizing the gain or loss as capital gain or ordinary income. ${ }^{19}$ In addition to the usual rules for characterizing rec-

(1982 \& West Supp. 1985). Cf. Helvering v. Bruun, 309 U.S. 461 (1940) (finding improvements to leased property to be income to the lessor upon forfeiture of the lease; this situation is now covered by I.R.C. $\S \S 109,1019$ (1982)).

11 See infra text accompanying notes 279-300.

12 See infra text accompanying notes 304-18.

13 See infra notes 304-24 and accompanying text.

14 See I.R.C. § 1001(a) (1982).

15 See id.

16 See I.R.C. § 1001(b) (1982).

17 See I.R.C. $\S \S 1001(\mathrm{a}),(\mathrm{b}), 1011$ (1982); see also D. Posin, Federal Income Taxation of InDividuals 151-69 (1983). These further adjustments generally involve tangible property held by corporations or individuals. Such adjustments would not generally be made to the basis of stock, other than with respect to commissions or other acquisition costs.

${ }^{18}$ See infra notes 308-18 and accompanying text.

19 See, e.g., I.R.C. $\$ \S 1221-1222$ (1982 \& West Supp. 1985) (requiring capital 
ognized gains and losses, the reorganization area provides some specialized rules of its own. ${ }^{20}$

These are the general principles that have governed the treatment of dispositions of property. While the principles themselves are reasonably straightforward, their application to the complex world of corporate acquisitions has proven to be an enormously difficult task. For over half a century, Congress, the courts, and the Treasury Department have struggled to formulate a consistent and sensible approach to these kinds of transactions.

\section{History of Corporate Reorganizations}

\section{A. Early Stirrings}

More than in most other areas of the tax law, the principles of corporate reorganizations are rooted in history. Some of the older principles still retain influence, and studying their historical evolution is a useful means of understanding their apparently illogical application to present-day transactions.

The predecessor of the modern corporate income tax was enacted in 1909, and the first modern income tax on individuals was enacted in 1913, after the passage of the sixteenth amendment to the Constitution. ${ }^{21}$ Yet, in the several years after the sixteenth amendment and the first corporate income tax were enacted, not a word about "corporate reorganization" was spoken, and the walls of the Republic did not come tumbling down.

In fact, the first stirrings in this hitherto nonexistent subject came not from Congress but from the Commissioner of Internal Revenue, who promulgated a series of rulings to the effect that exchanges of property or stock did not give rise to taxable income. ${ }^{22}$ Having stirred up the matter, the Commissioner in 1918 proceeded to retreat. $\mathrm{He}$ ruled that stock-for-stock exchanges in which the stock received had a greater par value than the stock given up and exchanges of property for stock both might result in taxable income. ${ }^{23}$ The precursor of present-

gains treatment when the transaction involves the sale or exchange of a capital asset). ${ }^{20}$ See infra notes 308-18 and accompanying text.

22 The first modern corporate tax was embodied in the Payne-Aldrich Tariff Act of 1909 , ch. $6, \S 38,36$ Stat. 11, 112, repealed by Act of Oct. 3, 1913, ch. 16, $\S 4(\mathrm{~S})$, 38 Stat. 114,201 . The sixteenth amendment, which legitimated the federal income tax on individuals, was necessitated by the Supreme Court's decision in Pollock v. Farmers' Loan \& Trust Co., 158 U.S. 601 (1895) (holding that the Income Tax Act of 1894, ch. 346, $\S \S 35-36,28$ Stat. 509, 559, was unconstitutional).

${ }_{22}^{2}$ See R. Paul, Studies in Federal Taxation 8 (3d ser. 1940).

${ }^{23}$ See id. (citing Treas. Reg. 33, arts. 101, 118-119 (1918)). 
day section 351 , allowing for a tax-free transfer of property to a controlled corporation, surfaced in 1919 with the Commissioner's ruling that a transfer of property to a corporation was not closed if the transferor owned more than fifty percent of the stock of the corporation. ${ }^{24}$

Higher rates are the mother of tax invention, and it was the tax act of $1917,{ }^{25}$ with unprecedentedly steep marginal rates designed to help finance World War I, that stimulated an interest in reorganization provisions. In 1919, Congress enacted the first statutory exclusion for income resulting from corporate reorganizations. ${ }^{26}$ This provision established a condition that has continued down to the present, namely, that for the exclusion to apply to an exchange of stock or securities, the exchange must be made in connection with a "reorganization, merger, or consolidation of a corporation."27 Gain on the exchange would be taxed only to the extent that the par or face value of the stock or securities received exceeded the par or face value of the stock or securities surrendered. ${ }^{28}$ This approach for taxing some of the gain is similar to the approach used in the current statute, except that the par value of stock in the current statute is quite rightly irrelevant to the question of taxability of the transaction. ${ }^{29}$ The entire scheme was put in the form of an exception to the general rule that exchanges of property are taxable events. ${ }^{30}$ A slight oversight of the Act was that it failed to define the essential terms "reorganization, merger, or consolidation." This little gap was filled by subsequent regulations and statutory enactments, and

24 See id. (citing Treas. Reg. 45, art. 1566). This ruling was later withdrawn, see T.D. 2924,1 C.B. 44 (1919), and matters in this area remained unclear until the enactment of the Revenue Act of 1921, ch. 136, 42 Stat. 227 (codified as amended in scattered sections of 26 U.S.C.). See id. $\S 202(c), 42$ Stat. at 230 (codified as amended at I.R.C. § 351(a) (1982)) (stating that no gain or loss shall be recognized when a person transfers property to a corporation and immediately thereafter is in control of that corporation).

25 Revenue Act of 1917, ch. 63, § 2, 40 Stat. 300, 301, repealed by Revenue Act of 1918, ch. 18, § 1400, 40 Stat. 1057, 1149 (1919).

${ }_{26}$ See Act of Feb. 24, 1919, ch. 18, § 202(b), 40 Stat. 1057, 1060 (1919), repealed by Revenue Act of 1921, ch. 136, § 1400, 42 Stat. 227, 320 .

27 Id.

28 Id.

29 See I.R.C. § 354(a)(2)(A)(i) (1982).

so See Act of Feb. 24, 1919, ch. 18, § 202(b), 40 Stat. 1057, 1060:

When property is exchanged for other property, the property received in exchange shall for the purpose of determining gain or loss be treated as the equivalent of cash to the amount of its fair market value, if any; but when in connection with reorganization, merger, or consolidation of a corporation a person receives in place of stock or securities owned by him new stock or securities of no greater aggregate par or face value, no gain or loss shall be deemed to occur from the exchange, and the new stock or securities received shall be treated as taking the place of the stock, securities, or property exchanged. 
it is filled to overflowing in the current statute and attendant regulations. ${ }^{31}$

At approximately the same time that these initial administrative and legislative steps were being taken, the first reorganization cases were beginning to take shape in the lower courts. These cases interpreted the statute as it read from 1913 through 1916, when it contained no references to reorganizations at all. The Supreme Court's pronouncements in these cases, ${ }^{32}$ issued during the 1920's, indicate the road not taken, illustrating what might have happened in the reorganization area had there been no statutory development. They also significantly influenced later statutory provisions.

The early reorganization cases can be understood only against the backdrop of the seminal case of Eisner $v$. Macomber. ${ }^{33}$ Macomber did not involve a reorganization, but it set a standard for determining taxability of corporate transactions with which the subsequent reorganization cases had to contend. In Macomber the Court held that it was unconstitutional to tax a shareholder on receipt of a pro rata stock dividend. ${ }^{34}$ The Court's theory in this case was that the stock dividend was not a gain severed from the capital of the corporation but simply a representation of the shareholder's continued investment. ${ }^{35}$ The corporation involved in the case had in fact been profitable, and the stock dividend was backed by an appropriate accounting transfer from earned surplus to capital account. ${ }^{38}$ Nonetheless, the Court found that to tax the pro rata stock dividend would be in effect to tax the appreciation in value of the shareholder's investment, rather than to tax the income from the investment. Taxing the appreciation in value was, in the Court's view, unconstitutional, whereas there was no question that a cash dividend would have been taxable. ${ }^{37}$

It is useful to focus in detail on the meaning of this case. On the day after the pro rata stock dividend, the shareholder clearly was no wealthier than the day before. The existence of the new shares in the hands of the shareholders of the corporation inevitably reduced the value of the original shares. Thus, the value of the new shares plus the

s1 See I.R.C. $\S 368(a)(1)$ (1982); Treas. Reg. § 1.368-1, T.D. 7745, 1981-1 C.B. 134; Treas. Reg. $\$ 1.368-2$, T.D. 7422, 1976-2 C.B. 108.

${ }^{32}$ See Marr v. United States, 268 U.S. 536 (1925); Cullinan v. Walker, 262 U.S. 134 (1923); Rockefeller v. United States, 257 U.S. 176 (1921); United States v. Phellis, 257 U.S. 156 (1921). These cases are discussed infra text accompanying notes 40-79.

ss 252 U.S. 189 (1920).

34 See id. at 211.

35 See id. at 209-11.

${ }^{36}$ Id. at 200.

37 See id. at 209. Taxability of stock dividends is now governed by I.R.C. $§ 305$ (1982), which in important respects follows the basic Macomber rule. 
original shares in the hands of the shareholder was equal to the value of her shares the day before the stock dividend: she still had the same percentage interest in the same corporation. This, however, was not the basis of the Court's decision. Nor could it have been. For it is also evident that if the corporation had paid a pro rata cash dividend, the stockholders would have been no wealthier on the day after the dividend than the day before. The value of the stockholder's shares just after she received the cash dividend would be reduced pro tanto because of the distribution of cash from the corporation. Thus, in both cases-the stock dividend and the cash dividend-the shareholder's wealth does not increase because of the transaction. But in the $\mathrm{Ma}$ comber view of the world only the shareholder in receipt of a cash dividend will pay tax: because of the severance of the income from the capital of the corporation, there has been a realizing event.

Macomber, a major case, was decided by a five-to-four vote, with Justices Holmes and Brandeis filing separate opinions. Justice Brandeis filed a long and vigorous dissent in which he argued that the stock dividend was in substance the same as if the corporation had offered stock for purchase on a pro rata basis to its shareholders and simultaneously declared a cash dividend equal to the amount that the shareholder would have to pay the company for the stock. ${ }^{38}$ In this latter instance, Brandeis argued, there was no question that the distribution of the cash dividend would have been taxable. Therefore, the pro rata stock dividend should itself be taxed. ${ }^{39}$ While Brandeis's approach did not carry the day, it presaged his approach in the subsequent reorganization cases that severely limited Macomber.

The first of these cases was United States v. Phellis, ${ }^{40}$ decided in 1921. Phellis involved the migration of the E.I. DuPont de Nemours \& Company from New Jersey to Delaware. ${ }^{41}$ To effect the transfer, DuPont's New Jersey subsidiary (DuPont New Jersey) transferred all of its assets to a new Delaware corporation, DuPont Delaware, in exchange for common stock and debentures of DuPont Delaware. ${ }^{42}$ The DuPont Delaware stock was then distributed to DuPont New Jersey's stockholders as a pro rata dividend. ${ }^{43}$ DuPont New Jersey remained alive as a holding company for the debentures and for a few other purposes. $^{44}$

s8 See Macomber, 252 U.S. at 220, 220-21 (Brandeis, J., dissenting).

39 See id. at 225 .

40257 U.S. 156 (1921).

41 See id. at 165.

$42 I d$. at 166.

4s Id. at 167.

44 Id. 
Phellis, an owner of 250 shares of New Jersey stock, received 500 shares of Delaware stock as a dividend under this arrangement. ${ }^{45}$ The Commissioner asserted that the 500 shares constituted income to Phellis in the amount of their fair market value. ${ }^{46}$ As the case developed, it appeared that the taxpayer had the better argument, in light of the Supreme Court's earlier decision in Macomber that a pro rata stock dividend does not constitute a realizing event. ${ }^{47}$ Like the shareholder in Macomber, the shareholder in Phellis owned the same proportion of shares in the same company after the stock dividend as he owned before. ${ }^{48}$

Surprisingly, however, the Supreme Court, speaking through Justice Pitney, reversed the Court of Claims, which had followed the $\mathrm{Ma}$ comber approach. In holding for the Commissioner, the Court reasoned that the stock dividend in Macomber had been stock of the distributing corporation, whereas in Phellis the dividend distributed by DuPont New Jersey involved the stock of DuPont Delaware. ${ }^{49}$ The fact was that DuPont Delaware was essentially the same corporation as DuPont New Jersey, except for being incorporated in a different state and having a greater amount of authorized capital stock. ${ }^{50}$ In the view of the Court, however, these factors were enough to take this case out of the Macomber rule of nontaxability. They meant that there had been a severance of income from capital, thereby triggering the "realizing event" required in Macomber for tax to be imposed. ${ }^{.1}$

A very similar approach was followed by the Court in Rockefeller v. United States, ${ }^{52}$ decided the same day as Phellis. Rockefeller involved the Prairie Oil \& Gas Company, incorporated in Kansas. Because of a previous Court decision establishing the jurisdiction of the Interstate Commerce Commission over pipeline operations, ${ }^{\text {,s }}$ the corporation decided to separate its oil business from its pipeline business. ${ }^{54}$ This was done by transferring the pipeline business to a new corporation, also incorporated in Kansas, and distributing the stock of that new

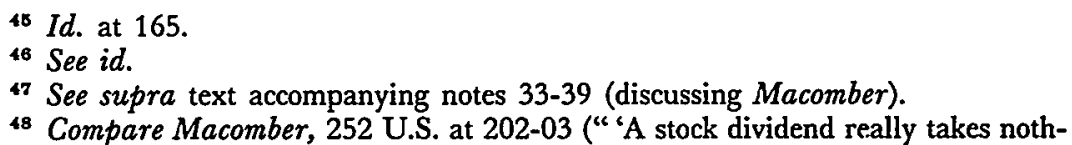
ing from the property of the corporation, and adds nothing to the interests of the shareholders." ") (quoting Gibbons v. Mahon, 136 U.S. 549, 559 (1890)) with Phellis, 257 U.S. at 168 .

49 See Phellis, 257 U.S. at 167.

so See id. at 167-68.

s1 See infra text accompanying notes 319-24.

52257 U.S. 176 (1921).

${ }^{53}$ See generally The Pipe Line Cases, 234 U.S. 548 (1914).

st See Rockefeller, 257 U.S. at 177-78. 
corporation immediately to the stockholders of Prairie. ${ }^{55}$

The Court, somewhat unexpectedly, regarded the Rockefeller case as indistinguishable from Phellis, notwithstanding that there was no change in state of incorporation in Rockefeller. The pro rata distribution of the stock of the new corporation was regarded as a realizing event that triggered taxation of the stockholders. The Court reached this conclusion in spite of the fact that, as it conceded, "there was apparently little but a reorganization and financial readjustment of the affairs of the companies concerned, here a subdivision of companies, without immediate effect upon the personnel of the stockholders, or much difference in the aggregate corporate activities or properties." In short, distribution of a stock dividend of any corporation other than the distributing corporation itself apparently constituted a realizing event. Thus Eisner $v$. Macomber was closely limited to its facts.

Cullinan $v$. Walker ${ }^{57}$ involved a complex transaction designed to enable the parties involved to accomplish the fashionable ends of the day, namely (1) to split an oil production company from an oil pipeline company, and (2) to change the state of incorporation to Delaware. ${ }^{\mathrm{s}}$ To accomplish these goals, the original Texas company was liquidated, and the trustees in liquidation organized two new Texas companies. To one they transferred the oil production assets; to the other, the pipeline assets. The trustees then organized a Delaware corporation, to which they transferred the stock of the two Texas companies in exchange for stock in the Delaware corporation. The trustees then distributed the stock and securities of the Delaware corporation on a pro rata basis to the former stockholders of the original Texas company. ${ }^{59}$ The Commissioner sought to impose a tax on the difference between the value of the stock and securities in the Delaware corporation that the taxpayers received and the cost of the taxpayers' stock in the original Texas company, yielding approximately $\$ 1.5$ million in income. ${ }^{60}$

Justice Brandeis, writing for the majority in an opinion that was foreshadowed by his dissent in Macomber, ${ }^{61}$ held that the transaction was taxable. ${ }^{62}$ This time Brandeis had Phellis and Rockefeller as am-

ss Rockefeller, 257 U.S. at 182-83. A second corporation involved in the Rockefeller case, the Ohio Oil Company, had the same problem as Prairie and undertook the same solution. The Court disposed of the two cases identically. See id.

${ }^{86} I d$. at 183.

57262 U.S. 134 (1923).

88 See id. at $135-37$.

89 Id.

6o See id. at 135.

- See supra text accompanying notes 38-39.

${ }^{62}$ Cullinan, 262 U.S. at 138. 
munition..$^{68}$ The taxpayer in Cullinan sought to distinguish Phellis and Rockefeller by arguing that in this case the transaction in question was a liquidating distribution rather than a stock dividend. ${ }^{84}$ However, Brandeis found that a liquidating distribution as well as a dividend distribution constituted a realizing event. ${ }^{65}$ It thus appeared that $M a$ comber had been so limited that any financial reorganization other than a straight pro rata stock dividend would be taxable.

Matters took another surprising turn, however, in the case of Weiss v. Stearn. ${ }^{66}$ Stearn also involved a financial reorganization in which the assets of one company were shifted to another company within the same state with no change in proportional ownership of the stockholders. As in Cullinan, the transaction was in form a liquidation. ${ }^{67}$ However, in Stearn, unlike the previous cases, the shareholders received half their consideration in cash. ${ }^{88}$ There was no question that the cash portion of the transaction was taxable. The issue in the case was the taxability of the stock portion of the consideration. ${ }^{68}$

Based on the previous cases, an observer could have thought that the stock portion of the transaction in Stearn would be taxable. But the Court found that the principles of Macomber should be applied to Stearn. ${ }^{70}$ Justice McReynolds, speaking for the Court, used language broad enough to reverse Phellis, Rockefeller, and Cullinan: "We cannot conclude that mere change for purposes of reorganization in the technical ownership of an enterprise . . . followed by issuance of new certificates, constitutes gain separated from the original capital interest."'1 Justices Holmes and Brandeis dissented on the grounds that the case was covered by Cullinan. ${ }^{72}$

The final decision of this early period was the celebrated case of Marr v. United States. ${ }^{73}$ Marr involved a shift in the state of incorporation of the General Motors Corporation from New Jersey to Delaware. The shareholders of General Motors New Jersey exchanged their stock for shares of General Motors Delaware. ${ }^{74}$ The New Jersey shareholders received almost exactly the same interest in the Delaware

63 See, e.g., id. at 137 (discussing Phellis and Rockefeller).

64 See id. at 137-38.

65 See id.

265 U.S. 242 (1924).

${ }^{67}$ See id. at 251-52.

es See id. at 252 .

${ }^{69}$ See id. at 251-52.

70 See id. at 253.

71 Id. at 254.

72 See id. (Holmes and Brandeis, JJ., dissenting).

73 268 U.S. 536 (1925).

74 Id. at 539. 
corporation.

Justice Brandeis, writing for the majority, held on the basis of the holdings in Phellis, Rockefeller, and Cullinan that the transaction was taxable. ${ }^{75} \mathrm{He}$ noted that Stearn had not involved a new state of incorporation (although that was also true in Rockefeller).$^{76}$ Brandeis asserted that Stearn was distinguishable from Marr because, while it was true that technically a new corporation had been formed in Stearn, "the corporate identity was deemed to have been substantially maintained." J7 Justice Brandeis also focused on slight changes in the capital structure of the new corporation that he interpreted as creating interests different from those that shareholders possessed in the old entity ${ }^{78}$ Justice McReynolds, the author of the Court's opinion in Stearn, joined in Justice Van Devanter's dissenting view that Stearn foreclosed taxation of the transaction in Marr. $^{79}$

The results of the cases in this early period can only be regarded as unsettling. Outcomes in Macomber and the other early reorganization cases seemed to depend not on predictable extensions of precedent, but rather on a power struggle between the Brandeis-Pitney wing and the McReynolds wing of the Court. Of the five reorganization cases decided by the Court over five years, only one was won by the taxpayer. And that case, Stearn, was the one in which taxation was perhaps most justified. Given the fifty percent cash distribution in Stearn, the resulting new, half-shrunken corporation was more unlike its predecessor than any of the newly formed entities in the other reorganization cases. Yet it was Stearn that was held to be closest to Macomber, in that it resulted in a new corporation whose identity was substantially maintained. ${ }^{80}$ Given the size of these transactions, and the large number of taxpayers holding stock in General Motors and the other large corporations involved, the lack of predictability in these cases was unacceptable.

Since the Court had apparently dropped the ball, it seemed appropriate for Congress to step in and pick it up. Congress did so, but then proceeded to fumble it. In retrospect it might have been better to let the Court continue to grapple with the problem.

75 See id. at 540.

7o See id. at 541; see also supra text accompanying notes 52-55.

77 Id. at 541.

78 See id. at 541-42.

79 See id. at 542 (Van Devanter, J., joined by McReynolds, Sutherland, and Butler, JJ., dissenting).

Bo See Stearn, 265 U.S. at 253-54. 


\section{B. Statutory Development}

As discussed above, the first stirrings in the statutory treatment of corporate reorganizations came in $1919 .^{81}$ Lengthy regulations were promulgated under the 1919 Act that established conditions under which shareholders would not be taxed in connection with a reorganization. The statute and the regulations were not confined to reorganizations of just one company, but also allowed the combination of two different companies to occur tax free. This was a major departure from the case law discussed above. ${ }^{82}$ The statute and regulations provided that the consideration received by the stockholders must be stock or securities in only one of the companies involved. Crude as the 1919 Act and its attendant regulations were, they set a number of themes that have continued down to the present, including the requirement that the transaction involved must be a reorganization, and the emphasis on the nature of the consideration to be received. At the same time, the helpfulness of the statute and regulations was limited by their focus on the importance of par value as a touchstone for the measurement of taxability. ${ }^{83}$

The 1921 Act began the process-still incomplete-of defining "reorganization." The Act generously provided that

[t]he word "reorganization," as used in this paragraph, includes a merger or consolidation (including the acquisition by one corporation of at least a majority of the voting stock and at least a majority of the total number of shares of all other classes of stock of another corporation, or of substantially all the properties of another corporation), recapitalization, or mere change in identity, form, or place of organization of a corporation, (however effected) ....84

By defining reorganization in this relatively sweeping language, Congress clearly sided with the McReynolds view of what should be nontaxable. ${ }^{85}$ Thus, even before the Brandeis-Pitney wing of the Supreme

81 See supra text accompanying notes $26-31$.

82 See cases discussed supra text accompanying notes 40-79.

83 See Act of Feb. 24, 1919, ch. 18, § 202(b), 40 Stat. 1057, 1060; Treas. Reg. 33, $\S \S 101,118-119$ (1918).

84 Revenue Act of 1921, ch. 136, § 202(c)(2), 42 Stat. 227, 230.

8s Justice McReynolds argued that transactions such as the one involved in Stearn, see supra text accompanying notes $66-72$, should not be taxable realization events to the extent that "[t]he practical result of the things done was, a transfer of the old assets and business, without increase or diminution or material change of general purpose, to the new corporation." Stearn, 265 U.S. at 252; see also Marr, 268 U.S. at 542 (Van Devanter, J., joined by McReynolds, Sutherland, and Butler, JJ., dissenting) 
Court began to win the judicial battles in this area, they were losing the legislative war.

In addition to providing greater specificity in the definition of the term "reorganization," the 1921 Act introduced two new types of reorganizations: "recapitalization" and mere "change in identity, form, or place of organization of a corporation, (however effected)." ${ }^{\text {B8 }}$ These two types of reorganization did not play much of a role in the early years.

Congress made the first of a number of major missteps by failing, in the 1921 Act, to provide special basis rules for transactions that qualified as tax-free reorganizations. Taxpayers remained subject to a cost basis rule, ${ }^{87}$ in which the cost of property acquired in an exchange equals the fair market value of the property given up, regardless of whether there has been any recognition of gain. Alert taxpayers and their advisers pounced on this opportunity to obtain a tax-free step-up in the basis of appreciated stock or other property, simply by involving such property in a qualifying tax-free reorganization. This higher basis would be of great use to taxpayers in further calculations of gain or loss on the property, as well as in calculations of depreciation and cost depletion. This easy tax avoidance scheme resulted in large revenue losses. ${ }^{88}$ Moreover, the 1921 Act excluded gain on exchanges of "like kind"89 property from the definition of income-an exclusion that allowed taxpayers simply to exchange stocks and bonds (as well as other property) tax free without reference to whether there was a reorganization at all.

Having created a statute with major loopholes in 1921, Gongress returned to the fray in 1923 to restrict the tax-free treatment of exchanges of stocks and bonds to transactions involving corporate reorganizations. ${ }^{80}$ Subsequently, in 1924 , Congress returned to the fray with a vengeance, enacting a comprehensive statute prepared at the Treasury Department. ${ }^{21}$ The 1924 statute is a remarkable accomplishment in its comprehensiveness and detail. It set down much of the language

("The practical result of the things done was [that] . . . [t] he business and assets were not materially changed, and the stockholder received nothing actually severed from his original capital interest .....").

Be Revenue Act of 1921, ch. 136, § 202(c)(2), 42 Stat. 227, 230.

87 Id. § 202(a), 42 Stat. at 227, 229.

See H.R. REP. No. 179, 68th Cong., 1st Sess. 7, 13 (1924).

${ }^{89}$ Revenue Act of 1921, ch. 136, $\S 202(c)(1), 42$ Stat. 227, 230. The current version of this provision does not apply to exchanges of stocks, bonds, and other securities. See I.R.C. $\S 1031($ a)(2) (1982 \& West Supp. 1985).

'oo See Revenue Act of 1923, ch. 294, 42 Stat. 1560.

91 See Revenue Act of 1924, ch. 234, 43 Stat. 253, discussed in A. BaAR \& G. Morris, Hidden Taxes in Corporate Reorganizations 16-18 (1935) (describing the role of the Treasury Department in the preparation of the statute). 
and many of the principles that currently govern the treatment of reorganizations.

The 1924 statute addressed in detail for the first time the treatment of a corporation that transfers property and receives stock in a reorganization but does not itself disappear. Such a corporation was granted tax-free treatment. ${ }^{82}$ The 1924 statute also provided for treatment of boot, finally eliminating the preoccupation with the par value of stock..$^{93}$ In addition, the statute allowed reorganization treatment on receipt of stock or securities without the surrender of stock, ${ }^{94}$ dealt with questions of earnings and profits, ${ }^{90}$ provided a separate and detailed definition of a "reorganization," an and promulgated substituted basis rules that prevented a tax-free basis step-up. ${ }^{97}$

The great detail of the 1924 Act marked a triumph in the Treasury Department of the approach advocated by A.W. Gregg, Special Assistant to the Secretary of the Treasury, who believed that a comprehensive statutory treatment was warranted. The competing approach, advocated by Dr. Thomas Adams, was that the statute should express general principles and leave it to the Treasury Department to develop specific regulations dealing with individual cases. Not surprisingly, the Treasury Department came to support Dr. Adams's view. Congress, however, adopted the Gregg approach. ${ }^{88}$

No major changes occurred until 1934, when once again agitation for an overhaul began to develop. The statute was proving inadequate to cope with the myriad forms of business arrangements that it was designed to cover, and tax avoidance under the reorganization provisions was resulting in an estimated revenue loss of $\$ 18$ million dollars annually. ${ }^{99}$ Three major tax avoidance techniques were employed: the sale of assets structured as a reorganization; the distribution of dividends in the form of stock in a subsidiary corporation; and the transfer of a favorable basis from one asset to another before its sale. ${ }^{100}$

As a result of these problems and the seeming inability of Con-

92 See Revenue Act of 1924, ch. 234, § 203(b)(3), 43 Stat. 253, 256 ("No gain or loss shall be recognized if a corporation a party to a reorganization exchanges property, in pursuance of the plan of reorganization, solely for stock or securities in another corporation a party to the reorganization.").

s3 See id. $\S 203(\mathrm{e}), 43$ Stat. at 257.

94 See id. § 203(c), 43 Stat. at 256.

9s See id. § 203(g), 43 Stat. at 257.

${ }^{96}$ See id. $\S 203(\mathrm{~h}), 43$ Stat. at 257.

${ }^{97}$ See id. § 204(a)(6)-(8), (10), 43 Stat. at 258-59.

88 For a description of the competition involving the approaches proposed by Adams and Gregg, see R. PAUL, supra note 22, at 24 n.81.

${ }^{99}$ See id. at 37 n.113.

100 See Sandberg, supra note 1, at 116. 
gress to enact a truly comprehensive statute that would lay all problems to rest, a subcommittee of the House Ways and Means Committee recommended total repeal of the reorganization provisions. ${ }^{101}$ In a reprise of the Gregg-Adams debate of ten years earlier, the Treasury opposed repeal on the grounds that the statute could be redrafted in more general terms, which would then give the Treasury and the courts power to deal with cases of abuse. Moreover, the Treasury was concerned that repeal of the reorganization provisions would lead to substantial revenue losses, given the declining stock values of that time. ${ }^{102}$

This concern over the loss of revenues seems to have been misplaced, inasmuch as a key provision of the 1934 legislation was a limitation on the deductibility of capital losses to $\$ 2000$ plus capital gains for the year. ${ }^{103}$ Also, if recognition of loss was sought, it was certainly possible to plan a transaction so as to avoid the reorganization provisions. ${ }^{104}$

Congress, however, rejected the idea of repeal. Keeping the existing statute in place, it simply amended it further to attempt to close up the three major tax avoidance loopholes of the time. These attempted statutory curatives were not especially effective. ${ }^{105}$

The 1934 provisions were incorporated into the 1938 statute and the Internal Revenue Code of 1939 virtually unchanged. ${ }^{106}$ Indeed, the statute did not change substantially in this area until the adoption of the 1954 Code. ${ }^{107}$ The 1954 Code did not alter the basic structure, but it did effect some significant modifications.

A major change of the 1954 legislation was that the corporate division provisions-split-ups, split-offs, and spin-offs-were separated from the reorganization provisions. Thus it was no longer necessary, after the 1954 Code, for a corporate division to qualify as a reorganization in order to enjoy nonrecognition of gain. ${ }^{108}$ This meant that a corporation could avoid recognition of gain in a corporate division without

101 See R. PAUL, supra note 22, at 37.

102 See Sandberg, supra note 1 , at 121, cited in R. PAuL, supra note 22, at 37.

103 See Revenue Act of 1934, ch. 277, § 117(d), 48 Stat. 680, 715 (1934) (codified as amended at I.R.C. $\S 165(\mathrm{f})(1982)$ ).

${ }^{104} C f$. United States v. Galveston-Houston Elec. Co., 84 F.2d 516 (1st Cir. 1936) (holding that lack of control by transferor defeated government's claim of a reorganization and allowing a $\$ 3$ million loss to wipe out a $\$ 2$ million gain incident to a bankruptcy proceeding).

${ }_{108}$ See Sandberg, supra note 1, at 116-20.

100 Compare Internal Revenue Code of 1939 , § 112(b)(2)-(4), (c)(1)-(2), (d)(1)(2), (e), (g)(1)-(2), (h)-(i), 53 Stat. 1, 37-40 with Revenue Act of 1934, ch. 277, $\S 117$ (d), 48 Stat. 680,715 (codified as amended at I.R.C. $\S 165$ (1982 \& West Supp. 1985)).

${ }_{107}$ Internal Revenue Gode of 1954, ch. 736, $\S 361,68$ A Stat. 118.

${ }^{108}$ See I.R.C. $\S \S 355,368$ (1982 \& West Supp. 1985). 
first transferring assets from the parent corporation to a subsidiary.

Treatment of shareholders in a corporate division was also altered. The active business requirement for the controlled subsidiary was added, ${ }^{109}$ as was the rule that the subsidiary's business could not be acquired in a recognition transaction within five years of the corporate division. ${ }^{110}$ Finally, Congress added a requirement that the parent corporation must continue to conduct an active trade or business after the division..$^{111}$

In addition to being separated from the rules governing corporate divisions, the rules for reorganizations were significantly changed. The basic structure remained intact, including the definition of a "reorganization" and the nonrecognition consequences to shareholders, security holders, and corporations involved in the reorganization. The six basic types of reorganization identified in the 1939 Code remained in the 1954 Code, although some important details of definition were changed. The definition of the basic Type A reorganization, the statutory merger or consolidation, was not changed. But the 1954 Code explicitly established the validity of a so-called "drop-down"-that is, a transaction in which some of the assets acquired in a reorganization could be dropped down to a subsidiary. ${ }^{112}$ Another significant result of the 1954 legislation was a major set of new rules for restricting the carryover of losses from one corporation to another in corporate combinations. ${ }^{113}$

The basic structure of the 1954 reorganization provisions survives today. ${ }^{114}$ In 1976 , the provisions limiting the transferability of loss carryovers in corporate combinations were overhauled, supposedly tightened, and-in the process-made even more complex. ${ }^{115}$ However, the effective date of the new provisions has been postponed several times, and they still have not gone into effect. ${ }^{216}$ The 1984 Deficit Reduction

109 Internal Revenue Code of 1954, ch. $1, \S 355(\mathrm{~b}), 68 \mathrm{~A}$ Stat. 114, 114 (current version at I.R.C. $\$ 355(\mathrm{~b})(1982)$ ). (1982)). (1982)).

${ }^{111} I d . \S 355(\mathrm{~b})(1)(\mathrm{A}), 68 \mathrm{~A}$ Stat. at 114 (current version at I.R.C. $\S 355(\mathrm{~b})(1)(\mathrm{A})$

${ }_{112}$ See $i d$. $\S 368(\mathrm{a})(2)(\mathrm{C}), 68 \mathrm{~A}$ Stat. at 121 (current version at I.R.C. $\S 368(a)(2)(\mathrm{C})(1982))$.

113 See id. $\S 382,68 \mathrm{~A}$ Stat. at 129-31 (current version at I.R.C. $\S 382$ (1982)).

114 See, e.g., I.R.C. $\S \S 354-356,358,368$ (1982 \& West Supp. 1985).

115 See Posin, Changes in the Taxation of Corporations Effected by the Tax Reform Act of 1976: Part II-Restrictions on Loss Carryover, 4 J. CORP. TAX'N 299, 306-32 (1978) (discussing amendments to I.R.C. $\$ \S 172(\mathrm{~b})(1)(\mathrm{B}),(\mathrm{b})(3)(\mathrm{E}), 382(\mathrm{a})$ (b)).

118 See Deficit Reduction Act of 1984, Pub. L. No. 98-369, § 62, 98 Stat. 494, 583 (postponing the effective date of the 1976 provisions to January 1, 1986). 
Act put into place a requirement that, in general, the transferor corporation in a Type $\mathrm{C}$ reorganization must liquidate in pursuance of the plan of reorganization. ${ }^{117}$

\section{G. The Judicial Doctrines}

Paralleling, or perhaps in counterpoint to, the statutory development described above, there has been a rich development of judicial law on the subject of reorganizations. Indeed, in places the judicial gloss is so heavy that the statute is invisible. It is remarkable and of great theoretical interest that in a subject so exhaustively covered by statute the case law should play such a critical role.

The judicial doctrines developed from the interplay between the early cases and the early statutory provisions. The early cases, discussed above, presented simple refinancing reorganizations, for which the income tax statute at the time was unprepared. The inconsistent results of the early cases provoked a statutory response, which, with its ambiguities and lacunae, stimulated the planning of more complex transactions and the growth of more elaborate judicial doctrines. Some of these doctrines were in turn adopted by later statutory amendments or by regulations. Others simply held sway in their own right as interpretations of the statute.

\section{Continuity of Interest}

\section{a. Historical Development}

A major judicial doctrine that grew out of the process described above is the requirement that a taxpayer seeking tax-free treatment in a reorganization have a "continuity of interest" with the assets she has transferred. This doctrine first surfaced in the Second Circuit case of Cortland Specialty Co. v. Commissioner, ${ }^{118}$ in which the Cortland Specialty Company, a closely held company engaged in buying and selling petroleum products, transferred substantially all of its assets to the Deyo Oil Company. The consideration received from Deyo was

117 See id. $\S 63,98$ Stat. at 584 (current version at I.R.G. $\S 368(\mathrm{a})(1)(\mathrm{C})$, (a)(2)(G) (1982 \& West Supp. 1985)); see also H.R. REP. No. 861, 98th Cong., 2d Sess. 844-45 (1984) (the conference committee's discussion of the distribution requirement in Type $\mathrm{C}$ reorganizations). The Deficit Reduction Act also loosened the control requirements for a nondivisive Type $\mathrm{D}$ reorganization in order to assist the Internal Revenue Service in combating the liquidation-reincorporation bailout technique. See Deficit Reduction Act of $1984, \S 64,98$ Stat. 494, 584 (current version at I.R.C. $\S 368(\mathrm{a})(1)(\mathrm{D})(1982)$ ).

11860 F.2d 937 (2d Cir. 1932). 
$\$ 53,070$ in cash and $\$ 159,750$ in notes with maturities ranging from two to fourteen months. ${ }^{119}$ The Second Circuit found that inherent in the term "reorganization" is the idea that there must be some continuity of interest on the part of the transferor or its stockholders to secure exemption from taxation under the reorganization provisions, asserting that "[r]eorganization presupposes continuance of business under modified corporate forms." 120 The court went on to hold that, even if there had been a reorganization, the taxpayer would have had to receive stock or securities in connection with the reorganization in order to obtain the exemption. The court found that short-term notes, which were doubtless readily tradable, did not constitute securities for this purpose. ${ }^{121}$

Cortland foreshadowed the Supreme Court case of Pinellas Ice $\mathbb{E}$ Cold Storage Co. v. Commissioner, ${ }^{122}$ although the Court in Pinellas eschewed the Second Circuit's phrase "continuity of interest."123 Pinellas involved the sale to a corporation of all of the assets of two St. Petersburg, Florida, ice companies under common control. In consideration, the purchasing corporation paid $\$ 400,000$ in cash and notes in the face amount of $\$ 1,000,000$. The notes were secured, carried an interest rate of six percent, and had various maturity dates, although none of these dates was later than four months from the date of the transaction. For the most part, the notes were paid before maturity; the selling corporations distributed the proceeds of the notes to their stockholders. ${ }^{124}$

It was not disputed that Pinellas Ice Company, the taxpayer, had realized a gain of $\$ 500,000$. The taxpayer maintained, however, that the gain should not be taxed, because the transaction was a reorganization under the applicable statute. The 1926 revenue statute provided, in a pattern similar to the present statute, that no gain or loss would be recognized if a corporation that was a party to a reorganization exchanged property solely for stock or securities in another corporation that was also a party to the reorganization. ${ }^{125}$ If some cash was received in the reorganization, the realized gain would be recognized. ${ }^{126}$ Thus, the 1926 statute, like the current Code, presented two questions: (1) Was there a reorganization? (2) Were stock or securities in a corpora-

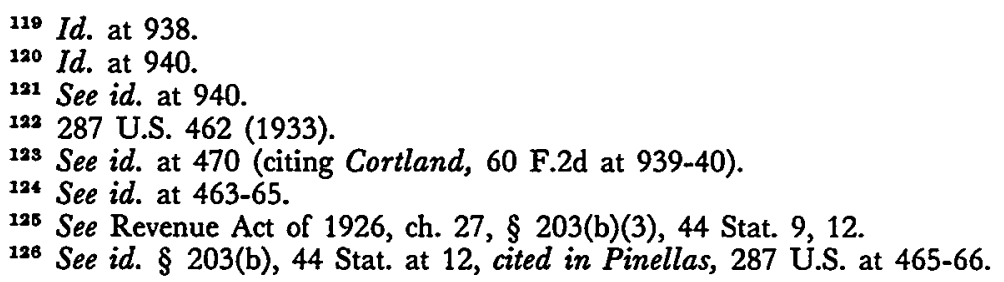


tion that was a party to the reorganization received as consideration by the taxpayer? ?27 $^{127}$

The answer to both questions had to be "yes" to result in nontaxability. It should be noted, however, that the first question was more significant than the second. If the answer to the first question were "no," then there would be no reorganization at all, and the taxpayer would be taxed on its entire realized gain. If, on the other hand, the answer to the first question were "yes," then the taxpayer would be taxed on its realized gain to the extent that the consideration it received did not consist of stock or securities.

The Court, speaking through Justice McReynolds, answered both questions "no," although answering either one "no" would have been sufficient to cause the transaction to be fully taxable. ${ }^{128}$ The Court's answers here laid the groundwork for both the "continuity of interest" doctrine and for the question of what constitutes a "security" for purposes of the statute.

As to the first question-whether the transaction constituted a reorganization-the transaction appeared at first blush to meet the literal terms of the statute. Thus the answer to the first question appeared to be "yes." The statute at that time defined a reorganization as "a merger or consolidation (including the acquisition by one corporation of at least a majority of the voting stock and at least a majority of the total number of shares of all other classes of stock of another corporation, or substantially all the properties of another corporation)."129 Because the purchaser-Florida West Coast Ice Company-acquired substantially all of Pinellas Ice Company's assets, the transaction appeared to be a reorganization under the statutory definition.

Nevertheless, the Supreme Court held that there was no reorganization ${ }^{130}$ - the answer to the first question was "no." The Court reasoned that

the mere purchase for money of the assets of one Company by another ... has no real semblance to a merger or consolidation. Certainly, we think that to be within the exemption the seller must acquire an interest in the affairs of the purchasing company more definite than that incident to ownership of its short-term purchase-money notes. ${ }^{131}$

${ }_{127}$ See id. $\S \S 202-203,44$ Stat. at 12-14.

128 See Pinellas, 287 U.S. at 468-70.

129 Revenue Act of 1926, ch. 27, § 203(h)(1), 44 Stat. 11, 14, cited in Pinellas, 287 U.S. at 466.

130 See Pinellas, 287 U.S. at 469.

$1 \mathrm{si} I d$. at 470 . 
The Court suggested that to hold otherwise would encourage tax evasion. ${ }^{132}$ The Court, therefore, read into the statute a requirement that the seller obtain a definite interest in the affairs of the purchasing corporation. For the Supreme Court, this marked the birth of the continuity of interest doctrine.

The extent of judicial lawmaking that the Pinellas Court undertook in applying the term "reorganization" would be justified only to avoid an absurd result or a result unacceptable on policy grounds. But an absurd or otherwise unacceptable result would not have followed had the Court found a reorganization to be present in Pinellas. Holding the transaction a reorganization would not have meant that the transaction was tax free, since the Court also held that the short-term notes were not securities. The Court found that " $[t]$ hese notes-mere evidence of obligation to pay the purchase price-were not securities within the intendment of the act and were properly regarded as the equivalent of cash." ${ }^{\text {133 }}$ Since gain in connection with a reorganization is recognized unless stock or securities are received, Pinellas Ice Company's entire gain would have been taxed even if there had been a "reorganization."134

The Court's second holding did not involve the heavy judicial lawmaking of the first. It is reasonable enough to regard notes with a fourmonth term as not being securities of a corporation, since the word "securities" generally connotes an instrument of longer term.

Thus, much less judicial interpretation would have been read into the statute if the Court had held that (1) there was a reorganization, but (2) the transaction was fully taxable because no securities had been received. Presumably courts, even the Supreme Court, should attempt to reach their results by putting as little gloss on the statute as possible.

In any event, not such dire consequences would have resulted if the Court had found that the transaction was not taxable. The transaction transferring the assets of the two ice companies to the Florida West Coast Ice Company was closed on December 15, 1926. ${ }^{135}$ The short-term notes came due at various times, none of them later than April 1, 1927..$^{136}$ If the transaction had been nontaxable in 1926, it would have been taxable in 1927 when the Florida company paid further cash and retired its notes. Thus, the extent of tax "evasion" that

132 See id.

18s Id. at $468-69$.

134 See Griswold, "Securities" and "Continuity of Interest," 58 HaRv. L. Rev. 705, 706-10 (1945). Dean Griswold was on the brief in the Pinellas case. See 287 U.S. at 463 .

19s Pinellas, 287 U.S. at 464.

136 Id. 
could have occurred was a one-year deferral. Of course, if longer-term notes had been used, the deferral would have been longer and thus more objectionable. But longer-term notes would have been regarded as securities, thus perhaps qualifying the transaction as a reorganization and allowing for deferral of the taxpayer's gain on the notes. Hence, if the Supreme Court had followed the literal language of the statute and held the transaction not taxable, no great yawning chasm of tax deferral or avoidance would have been opened.

Moreover, the above analysis indicates that no significant tax avoidance was even being attempted by the taxpayer in Pinellas. As pointed out above, the deferral that would have resulted if the taxpayer had prevailed was one year. The transaction was closed on December 15, 1926. ${ }^{137}$ Presumably, it would have been possible to delay the closing until 1927, if there had been a major tax advantage to one of the parties in so doing. There is certainly nothing in the opinion of the Court to suggest that any particularly egregious tax avoidance or advantage was attempted in this case.

In choosing Pinellas to make a major interpretive decision on a new statute, the Court chose a particularly weak case. The Court should have waited until it was actually confronted with a case of tax -avoidance. Because it did not, more was read into the statute than necessary, and the clarity and consistency of the Court's future decisions in this area suffered as a result. Notwithstanding the shaky bases on which Pinellas rested, it gave birth to two major judicial lines of development that continue to influence the law of reorganizations: the requirement of a continuity of interest, and the definition of "security." If Pinellas had been decided more soundly, the subsequent development of the case law in the field of reorganizations almost certainly would have been different. ${ }^{138}$

The Pinellas Court required the existence of a "continuity of interest." However, since on the facts of the case the Court decided that a continuity of interest was not present, it provided little information on what facts would satisfy this requirement. Would "securities" in the form of long-term bonds be enough, or was stock required?

The case of Helvering $v$. Minnesota Tea Co ${ }^{139}$ represented a major development in this area of the law. The Minnesota Tea Company transferred substantially all of its assets to Grand Union for $\$ 426,843$ cash plus voting trust certificates representing 18,000 shares of Grand

138 Cf., e.g., Camp Wolters Enters. v. Commissioner, 22 T.C. 737, 750-51 (1954) (citing Pinellas in explaining which debt obligations can be termed "securities").

139296 U.S. 378 (1935). 
Union stock. ${ }^{140}$ The Court, in an opinion by Justice McReynolds, held that the transaction was a reorganization because "the seller acquired a definite and substantial interest in the purchaser."141 Although the stock constituted only $55.85 \%$ of the value of the consideration, the Court was willing to find a reorganization "so long as the taxpayer received an interest in the affairs of the transferee which represented a material part of the value of the transferred assets."142

The significance of Minnesota Tea lies in its finding that a reorganization had occurred despite the receipt of a substantial amount of cash. ${ }^{143}$ In this respect, the Court's opinion was reminiscent of the Stearn case discussed above. ${ }^{144}$ After Minnnesota Tea, it was clearly unnecessary to have $100 \%$ continuity of interest for a reorganization; at least $55.85 \%$ would do. It should be borne in mind that this was done with no statutory guidance whatsoever. The Court, with some help from the Second Circuit, invented the continuity of interest doctrine in Pinellas $^{145}$ and then began to refine it and cut it back in Minnesota Tea.

But the genie was out of the bottle. The Court, having created the continuity of interest requirement, was now obliged to define its reach. It began that process in John A. Nelson Co. $v$. Helvering, ${ }^{\mathbf{1 4 6}}$ decided along with Minnesota Tea. In this case, the Elliot-Fisher Gorporation, under an agreement with the Nelson Company, organized a new corporation with 30,000 shares of common stock and 12,500 shares of nonvoting preferred stock. ${ }^{147}$ Elliot-Fisher then transferred $\$ 2,000,000$ in cash to the new corporation in exchange for all of that corporation's common stock. ${ }^{148}$ The Nelson Company then transferred substantially all its property to the new corporation and in return received the $\$ 2,000,000$ in cash plus all the nonvoting preferred stock. The preferred stock constituted $38.46 \%$ of the consideration, with the balance in cash. $^{148}$

It might have been thought, based on the cases discussed above, that this transaction would not qualify as a reorganization. While it met the literal terms of the statute, in that there had been a transfer of

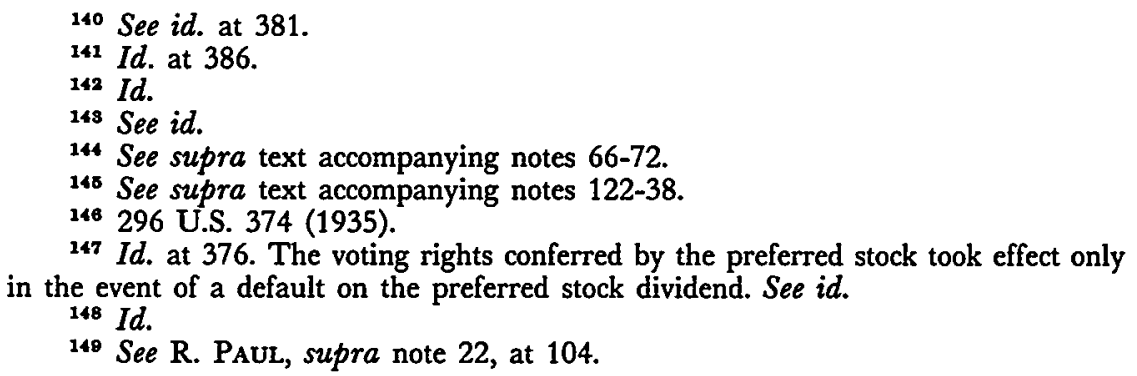


substantially all of the corporation's assets, the transaction seemed to fall far short of the continuity of interest requirement defined in earlier cases. Nonvoting preferred stock certainly confers a much weaker proprietary interest than the 18,000 shares of common stock received by the taxpayer in Minnesota Tea.

Nevertheless, the Court reversed the lower court and held that the transaction constituted a reorganization. ${ }^{100}$ Taking notice of Pinellas, the Court found that

the seller acquire[d] a definite and substantial interest in the affairs of the purchasing corporation .... The owner of preferred stock is not without substantial interest in the affairs of the issuing corporation, : although denied voting rights. . . . A controlling interest in the transferee corporation is not made a requisite by [the provisions governing reorganizations]. ${ }^{151}$

Since nonvoting preferred stock passed muster, the question arose whether long-term bonds would meet the continuity of interest requirement. This issue came up in an interesting form in Helvering $v$. Watts. ${ }^{152}$ Watts was one of three shareholders of Ferro Alloys Corporation, all of whom exchanged their stock in Ferro Alloys for approximately $\$ 963,000$ worth of stock in Vanadium Corporation of America and $\$ 1,161,184$ in mortgage bonds of Ferro Alloys. ${ }^{163}$ Thus, the stock was about forty-five percent of the consideration, and the bonds were the balance. The Court, citing Minnesota Tea, held that the transaction was a reorganization..$^{154}$

There are two ways of looking at the holding in Watts. Either the Court viewed the stock and bonds together as being necessary to satisfy the continuity of interest requirement, or it viewed the stock alone as sufficient and the bonds as just tagged on. The closest the Court came to answering that question was its statement that "[t]he bonds . . . were securities within the definition [of reorganization] and cannot be regarded as cash, as were the short term notes . . . in [Pinellas]."168 That comment might have meant that as securities the bonds did help fulfill the continuity of interest requirement. Or it might have meant that the stock alone fulfilled the continuity of interest requirement, and the bonds as securities were simply not taxable as cash, as were the

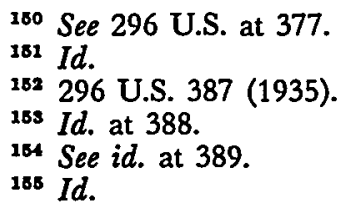


short-term notes in Pinellas.

Therefore, after Watts the question remained: Could bonds alone satisfy the continuity of interest requirement? This issue arose in LeTulle v. Scofield, ${ }^{158}$ decided by the Supreme Court in 1940, five years after Nelson, Minnesota Tea, and Watts. Letulle was the sole stockholder of Gulf Coast Irrigation Company, the owner of irrigation properties. ${ }^{157}$ Pursuant to an agreement with the Gulf Coast Water Company, LeTulle transferred property he personally owned to Gulf Coast Irrigation, and then Gulf Coast Irrigation transferred substantially all of its assets to Gulf Coast Water in exchange for $\$ 50,000$ in cash and $\$ 750,000$ in Gulf Coast Water bonds, payable serially with maturities ranging from about fourteen months through twelve years. ${ }^{158}$

The Court held-contrary to a series of earlier lower court decisions applying Minnesota Tea, Nelson, and Watts, ${ }^{159}$-that the receipt of bonds alone or bonds and cash did not confer a proprietary interest on the transferor, and hence that the transaction was not a reorganization. ${ }^{160}$ The Court found that the bonds, even though secured solely by the assets transferred, did not represent a proprietary stake sufficient to establish a continuity of interest. ${ }^{101}$

These early cases, ending with LeTulle, established the general contours of the continuity of interest doctrine. It appeared from these cases that continuity of interest required some form of equity consideration, even if it was only nonvoting preferred stock. Long-term bonds by themselves were not enough. Moreover, the doctrine required that some minimum amount of equity-at least thirty-eight percent-be involved in the transaction.

Since these early cases, the statute and the regulations have carried the doctrine forward to the present. In particular, the Code and the Treasury regulations set forth specific requirements for the percentage

166308 U.S. 415 (1940).

157 Id. at 416.

168 Id.

158 See, e.g., Burnham v. Commissioner, 86 F.2d 776 (7th Cir. 1936) (no loss recognized on an exchange of promissory notes pursuant to a reorganization); Lilienthal v. Commissioner, 80 F.2d 411 (9th Cir. 1935) (stockholder who received cash and bonds in exchange for stock under a reorganization plan not subject to tax on the bonds); $c f$. Worcester Salt Co. v. Commissioner, 75 F.2d 251 (2d Cir. 1935) (parent corporation's purchase of the assets of its wholly owned subsidiary in return for the parent's bonds held not a reorganization, despite falling within the literal terms of the statutory language).

${ }^{160}$ See LeTulle, 308 U.S. at $420-21$.

161 See id. During this period the Supreme Court also held that assumption of the transferor's liabilities and payment thereof was taxable boot and did not contribute to meeting the continuity of interest requirement. See United States v. Hendler, 303 U.S. 564, 566-67 (1938). 
of stock that must be received as consideration in stock-for-stock (Type B) and stock-for-assets (Type $\mathrm{C}$ ) reorganizations. ${ }^{\mathbf{1 0 2}}$ Cases, regulations, and rulings continue to govern the level of equity required as consideration in a Type A merger or consolidation. A Fifth Circuit opinion, for example, held that a merger or consolidation in which equity was less than one percent of the total consideration did not qualify for treatment as a reorganization. ${ }^{163}$ On the other hand, the Internal Revenue Service will rule favorably if at least fifty percent of the aggregate consideration received is stock, ${ }^{104}$ and courts have held that less than fifty percent may be sufficient. ${ }^{165}$ Furthermore, there have been a variety of refinements in the continuity of interest doctrine, many of which have become quite technical. ${ }^{168}$

Curiously, the doctrine has also come to include the requirement that there be continuity of shareholder identity before and after the transaction ${ }^{\mathbf{1 6 7}}$ - a requirement not included in the classic continuity of interest doctrine. The doctrine has also spawned the related doctrine of continuity of the business enterprise involved in the transaction. ${ }^{168} \mathrm{De}-$

${ }^{162}$ For example, all of the consideration in a stock-for-stock reorganization must be voting stock. See I.R.C. $\S 368(a)(1)(B)(1982)$. In return for this consideration, the acquiring firm must obtain "control," which is generally defined as "the ownership of stock possessing at least 80 percent of the total combined voting power of all classes of stock entitled to vote and at least 80 percent of the total number of shares of all other classes of stock of the corporation." I.R.G. $\$ 368(c)(1)$ (West Supp. 1985). Similarly specific requirements apply to the stock-for-assets reorganization. See I.R.C. $\S 368(\mathrm{a})(1)(\mathrm{G}),(\mathrm{a})(2)(\mathrm{B})(1982)$; Treas. Reg. $\S 1.368-2(\mathrm{~d})$, T.D. 6152, 1955-2 I.R.B. 61, 202; see also infra text accompanying notes 279-324.

${ }_{163}$ See Southwest Natural Gas Co. v. Commissioner, 189 F.2d 332, 335 (5th Cir.), cert. denied, 342 U.S. 860 (1951).

164 See Rev. Proc. 77-37, § 3.02, 1977-2 C.B. 568, 569.

105 Compare, e.g., Nelson, 296 U.S. 374, 376 (38\% enough) and Miller v. Commissioner, 84 F.2d 415, 418 (6th Gir. 1936) (25\% enough) with Yoc Heating Corp. v. Commissioner, 61 T.C. 168, 177 (1973) (15\% not enough). In Kass v. Commissioner, 60 T.C. 218 (1973), affd mem., 491 F.2d 749 (3d Cir. 1974), Kass, a small minority stockholder in a corporation that was being merged into another firm, received stock in the merged corporation in exchange for her stock in the disappearing corporation. Although Kass received no cash in this transaction, other stockholders received a large enough proportion of cash that the transaction as a whole did not satisfy the "continuity of interest" requirement. Kass therefore had taxable gain, even though she had received no cash and the transaction was out of her control. See Kass, 60 T.C. at 227; see also Wolfman, "Continuity of Interest" and The American Law Institute Study, 57 TAXES 840, 842 (1979). For further discussion of Kass, see infra text accompanying notes 393-94.

${ }_{188}$ See generally Hutton, Musings on Continuity of Interest-Recent Developments, 56 TAXES 904 (1978).

${ }_{167}$ See Rev. Proc. 77-37, § 3.02, 1977-2 C.B. 568, 569 (indicating that sales, redemptions, and other dispositions of stock occurring prior or subsequent to the exchange will be considered in determining whether the continuity of interest requirement is satisfied).

${ }_{188}$ See Treas. Reg. $\S 1.368-1$ (b), (d), T.D. 7745, 1981-1 G.B. 134, 140-41 (effective for acquisitions occurring after Jan. 30, 1981). These rules provide in general 
spite, or perhaps because of, such refinements over the course of its relatively long history, the continuity of interest doctrine presents a number of still unresolved problems.

\section{b. Current Issues}

\section{i. Required Period of Continuity}

One major unresolved question is whether there is any particular time period, before and after the reorganization, during which the requisite continuity of interest must exist. This question is important because in many cases the transferor may have an intention or commitment to dispose of the stock in the acquiring corporation soon after it is received.

Such was the case in McDonald's Restaurants v. Commissioner, ${ }^{169}$ in which the McDonald's Corporation bought the operations of one of its franchisees in a statutory merger under Delaware law. ${ }^{170}$ The sellers, the Garb-Stern group, wanted all cash as their consideration. McDonald's, however, wanted to give all stock, so it could take advantage of "pooling of interests" accounting. ${ }^{171}$ As a compromise, the parties agreed that McDonald's would give all stock but would include the stock in a registration and sale of stock to the public planned for six months thereafter, so that the Garb-Stern group could get cash for their stock. ${ }^{172}$ The Garb-Stern group could choose in the alternative to par-

that the acquiring corporation, $P$, can satisfy the "continuity of business enterprise" requirement by satisfying either one of two tests: (i) continuing $T$ 's historic business or (ii) using a significant portion of $T$ 's historic business assets in a business.

The "historic business" test is deemed to be satisfied by the regulations if $P$ continues $T$ 's previous business. If $T$ has more than one line of business, the test requires only that $P$ continue a significant line of $T$ 's business. A corporation's historic business is the business that it has conducted most recently, not a business that the corporation enters into as part of the plan of reorganization itself. $T$ cannot suddenly go into a business consistent with that of its prospective parent, $P$, just to satisfy the rules governing continuity of business enterprise.

The asset continuity test is satisfied if $P$ uses a significant portion of $T$ 's historic business assets in a business-whether or not it is the business in which $T$ used the assets. In addition to stock and securities, $T$ 's business assets may include intangible operating assets such as good will, patents, and trademarks, whether or not they have a tax basis. For five examples of the application of these rules, see $i d$.

169688 F.2d 520 (7th Cir. 1982).

170 See id. at 523 .

171 "Pooling of interests" accounting, for these purposes, involves retaining the historical bases of the acquired business's assets. In addition, income of the acquired corporation is included in the combined corporation's income for prior fiscal periods as well as the period in which the combination occurs. See id. at 521 n.2.

$172 I d$. at 521-22. If the stock that the Garb-Stern group received had remained unregistered, it could have been sold only pursuant to SEC Rule 144, 17 C.F.R. $\S 230.144$ (1984), which provides that unregistered stock sold pursuant to a private 
ticipate in any later registration and sale of stock that McDonald's might initiate during the following six years. ${ }^{173}$ The group could also choose not to sell its stock at all, although it fully expected to do so. In fact, six months after the sale, and in the same taxable year as the sale, McDonald's registered and sold a new issue of stock. The Garb-Stern group "piggy-backed" its shares in that sale and thus ultimately wound up with cash. ${ }^{174}$

At issue in the case was the tax basis of the assets for purposes of depreciation in the hands of McDonald's. Because of the particular facts, the Commissioner and taxpayers transposed their customary positions. The Commissioner argued that a reorganization was present and that a low carryover basis should therefore be used. ${ }^{175} \mathrm{McD}$ Donald's argued that the merger for stock and the sale by the Garb-Stern group of all of its stock for cash six months later should be treated as one transaction, thereby defeating continuity of interest. ${ }^{176}$ The Court held in favor of McDonald's. Thus the sale for cash by the Garb-Stern group broke post-reorganization continuity. ${ }^{177}$

This discussion leaves unanswered the question of how long after the reorganization the stock must be held in order to maintain continuity of interest. In one ruling the IRS suggested that five years of unrestricted ownership will ordinarily be sufficient to establish postreorganization continuity. ${ }^{178}$ However, that ruling involved special cir-

placement must be held for two years, and after that can be sold only in amounts limited to the lesser of one percent of the shares or the average weekly reported volume of trading in such securities on all securities exchanges during the four calendar weeks preceding the sale. See $i d$. $\S 230.144(d)(1)$, (e)(2).

173 McDonald's, 688 F.2d at 522 . The Garb-Stern group also had a right to demand registration in the event that $\mathrm{McDonald}$ 's did not undertake a registration and sale within one year of the transaction. Id.

174 Id.

178 See id. at 523 (referring to the basis treatment of acquired assets in a reorganization under I.R.C. $\S 362$ (b) (1982)).

178 See 688 F.2d at 524.

177 The court agreed with the Tax Court's determination that the transactions should be combined-stepped together-under the "end result" and "interdependence" tests: two out of the three tests generally used for determining the applicability of the step transaction doctrine. Even under the most restrictive "binding commitment" test, the court felt that the transactions might very well be stepped together, given the fact that it was an essential element of the agreement that the Garb-Stern group could force McDonald's to register and sell its stock. See id. at 524-25.

${ }_{178}$ See Rev. Rul. 66-23, 1966-1 C.B. 67, 68. In Revenue Ruling 66-23, the IRS found that a seven-year period of unrestricted ownership was sufficient to establish post-reorganization continuity of interest. In reaching this conclusion, however, the IRS also noted that a five-year period would "ordinarily" be sufficient. Id. The Service has since cited this ruling in support of a five-year test. See Rev. Rul. 78-142, 1978-1 C.B. 111,113 (ruling that receipt of mandatory serial redemptions of preferred stock in a reorganization did not violate continuity of interest where such redemptions could not commence until five years after the reorganization). The IRS has also stated that in its 
cumstances: the taxpayer, for antitrust reasons, was under a court order to dispose of the stock received in a merger within seven years. Moreover, the Commissioner stated in the ruling that even if the taxpayer disposed of some or all of the stock within five years, the status of the reorganization would not be affected, because at the time of the reorganization the taxpayer had no preconceived plan or arrangement to sell the shares. ${ }^{178}$ Thus, while five years is a safe harbor in this area, even less than five years of post-reorganization continuity might suffice if there is no preconceived plan or arrangement to dispose of the stock at the time of the reorganization. There is, however, considerable uncertainty about this question; the cases and rulings have not clearly defined the circumstances under which periods of less than five years will establish a continuity of interest.

\section{ii. Arbitrage}

Arbitrage activity in acquisitions involving publicly held companies can raise both post-reorganization and pre-reorganization continuity problems. The IRS has stated that in its rulings it will take into account sales, redemptions, and other dispositions of stock occurring prior to the exchange. ${ }^{180}$ The question is whether this covers the activities of arbitrageurs ${ }^{181}$ whose transactions in the stock of a target company are not part of the plan of reorganization.

The Senate Finance Committee's Preliminary Staff Report on the Income Taxation of Corporations ${ }^{\mathbf{1 8 2}}$ points out that, despite the Service's statement that for ruling purposes pre-reorganization turnover of stock ownership could undermine continuity of interest, there are no cases holding that arbitrage activity destroys pre-reorganization con-

rulings it will take into account sales, redemptions, and other dispositions of stock that are "part of the plan of reorganization," whether "prior or subsequent to the exchange." Rev. Proc. 77-37, 1977-2 C.B. 568, 569.

179 See Rev. Rul. 66-23, 1966-1 C.B. 67, 68.

180 See supra note 178.

181 In general, arbitrageurs in corporate acquisitions analyze announced takeovers and then, if the situation looks attractive, take a position that will be profitable if the transaction goes through. For example, in a transaction in which the parent offers stock, buying the stock of the target and selling short the stock of the parent will insulate the arbitrageur from market risk and allow her to win or lose based on the results of the transaction. Where the transaction is for cash, arbitrageurs will hedge their market risk in other ways, for example by buying puts on a market index. The players in the sophisticated arbitrage game generally are the leading investment banking firms. See G. Wyser-PratTe, Risk Arbitrage II 4 (Monograph Ser. in Fin. \& Econ. No. 3-4, 1982).

182 Staff of Senate Comm. on Finance, 98th Cong., 1st Sess., PrelimiNARY REPORT ON THE REFORM AND SIMPLIFICATION OF THE INCOME TAXATION OF Corporations 30 (Comm. Print 1983) [hereinafter cited as Preliminary Report]. 
tinuity, even though arbitrage is common in takeovers involving publicly held companies. ${ }^{183}$ The Preliminary Report suggests that arbitrageurs frequently acquire as much as ninety percent of the target's stock and that this type of activity is a serious problem in the continuity of interest area. ${ }^{184}$

The committee staff has, however, misapprehended the relationship of arbitrage activities to continuity of interest theory. First, a high proportion of acquisitions-those conducted solely for cash-do not raise continuity of interest issues. ${ }^{185}$ Second, even where the consideration is stock, once the transaction is consummated arbitrageurs are usually quick to dispose of their newly received stock in the parent in order to realize their profits and free their capital (most of which is borrowed) for the next transaction. ${ }^{186}$ Thus, the arbitrageurs will be taxed in full on the transaction, ${ }^{187}$ whether or not the transaction is taxable to the other shareholders of the target. Therefore, if the activity of the arbitrageurs destroys continuity of interest, the other shareholders, not the arbitrageurs, will suffer the consequences.

This raises the question of how much pre- or post-reorganization arbitrage there must be in order to create continuity of interest problems for the other shareholders. There are three possible approaches to this problem.

First, it could be said that arbitrage activity before or after the reorganization is simply not a problem at all. A very large turnover of stock prior to the reorganization should not affect continuity of interest. The stock is still outstanding and still held by investors who will receive appropriate consideration for their stock in the reorganization. This would be consistent with the historical development of the continuity of interest doctrine, discussed above, wherein the focus was on the nature of the consideration received in the reorganization, not the changes in the stock ownership before or after the reorganization. ${ }^{188}$ Indeed, the IRS has apparently taken this approach, inasmuch as there are no cases or rulings that have held that arbitrage activity before or

183 See id.

184 See id.

185 For a general idea of the proportion of cash transactions, see U.S. Mergers and Acquisitions, MERGERs \& AcQuisrTIONS, Spring 1984, at R1-R57 (setting forth prices and terms of completed mergers, acquisitions, and divestitures reported in the fourth quarter of 1983).

${ }_{188}$ This hasty exit by the arbitrageurs customarily depresses the post-reorganization price of the parent. See Post Merger Selling Pressure, VAlue Line Merger Evaluation Service, May 5, 1969, at 1.

187 In general, the arbitrageurs, as dealers in securities, would be taxed at ordinary income rates. See I.R.C. § 1236(a) (1982 \& West Supp. 1985).

${ }^{188}$ See supra text accompanying notes 118-68. 
after the reorganization destroyed continuity of interest. ${ }^{189}$

Nevertheless, the Preliminary Report suggests that a large amount of pre-reorganization arbitrage should break continuity of interest. ${ }^{100}$ In support of this position, the Report cites Revenue Procedure 77$37,{ }^{191}$ which states in part that

[t]he "continuity of interest" requirement of section 1.3681(b) of the Income Tax Regulations is satisfied if there is continuing interest through stock ownership in the acquiring or transferee corporation ... on the part of the former shareholders of the acquired or transferor corporation which is equal in value, as of the effective date of the reorganization, to at least 50 percent of the value of all of the formerly outstanding stock of the acquired or transferor corporation as of the same date. It is not necessary that each shareholder of the acquired or transferor corporation receive in the exchange stock of the acquiring or transferee corporation, or a corporation in "control" thereof, which is equal in value to at least 50 percent of the value of his former stock interest in the acquired or transferor corporation, so long as one or more of the shareholders of the acquired or transferor corporation have a continuing interest through stock ownership in the acquiring or transferee corporation .... which is, in the aggregate, equal in value to at least 50 percent of the value of all of the formerly outstanding stock of the acquired or transferor corporation. Sales, redemptions, and other dispositions of stock occurring prior or subsequent to the exchange which are part of the plan of reorganization will be considered in determining whether there is a 50 percent continuing interest through stock ownership as of the effective date of the reorganization. ${ }^{192}$

It is clear from this quotation that with respect to pre-reorganization activity the IRS is primarily concerned with the nature of the consideration to be received by the shareholders of the acquired or transferor corporation, rather than pre- or post-reorganization trading activity in the stock of the acquired or transferor corporation. This is, of course, entirely consistent with the historical development of the continuity of

189 See supra text accompanying note 183.

180 Preliminary Report, supra note 182, at 30 (describing the Service's treatment of arbitrage activity and asking the question, "If continuity of interest is important after an acquisition, why should it be effectively irrelevant before?").

191 1977-2 C.B. 568.

102 Id. at 569. 
interest doctrine. In the $M c$ Donald's case, ${ }^{183}$ for example, the court held that subsequent sales of the stock received as consideration by the shareholders of the acquired corporation broke continuity of interest when the subsequent sales were for cash and were part of an overall integrated plan by the selling shareholders. ${ }^{194} \mathrm{Had}$ those subsequent sales not been made pursuant to an integrated plan, however, the court probably would have held that continuity of interest was maintained.

Thus, it would be consistent with the historical development of the continuity of interest doctrine to hold that pre- and post-reorganization turnover of stock ownership, of the kind that is customarily engaged in by arbitrageurs, does not destroy continuity of interest. This, in fact, seems to be the Service's position.

A second approach to the question of the effect of arbitrage on continuity of interest is to go to the other extreme and say that any sales of stock before or after the reorganization are counted against continuity of interest. Thus, in a Type B reorganization, for example, where only voting stock may be used as consideration, ${ }^{195}$ it could be said that any turnover in stock ownership of the target before or after the reorganization, whether due to arbitrage or other transactions, and whether or not part of the plan of reorganization, would destroy continuity of interest. This hardly seems like an appropriate result: it is not at all consistent with the historical development of continuity of interest doctrine, and there is no current authority to support it. Thus, this approach may be dismissed with confidence.

The third approach is to apply the well-established fifty percent test to the question of how much turnover in stock ownership, whether due to arbitrage or other transactions, may occur before or after the reorganization. In effect, this would set up a two-track continuity of interest test: a continuity of interest test related to nature of consideration (the traditional test) and a continuity of interest test related to turnover in stock ownership. For example, in a Type B reorganization, the statute itself insures that the "nature of consideration" test is met by requiring that the consideration be solely voting stock. The turnover test might impose a maximum of fifty percent turnover in stock ownership with respect to the shareholders of the target before or after the reorganization. Thus a Type $B$ reorganization in which the consideration was solely voting stock and in which there was a forty percent turnover in stock ownership due to arbitrage would be a valid reorganization.

I8s See supra text accompanying notes 169-77.

194 See McDonald's, 688 F.2d at 25.

195 See I.R.C. § 368(a)(1)(B) (1982). 
This third alternative may sound complex or unlikely to be implemented, but in fact there is some evidence that the Service is following it. In a 1979 letter ruling, ${ }^{196}$ the Service dealt with a proposed reverse triangular Type A reorganization, ${ }^{197}$ a transaction that, like the Type $\mathrm{B}$ reorganization, requires the acquiring corporation to obtain at least eighty percent of the target corporation's stock. ${ }^{108}$ This requirement assured that the historical continuity of interest test was easily met with respect to the nature of the consideration. However, the IRS stated as one of its further conditions for issuing a favorable advance ruling that the parties have no knowledge of any intention on the part of the shareholders to turn over more than fifty percent of their ownership of the stock after the reorganization. ${ }^{189}$ This letter ruling thus evidences a two-track approach to continuity of interest: there must be the proper type of consideration, and the contemplated turnover in share ownership must be limited to fifty percent.

The implications of these three approaches for the activities of arbitrageurs are fairly clear. If the first approach is taken, even extensive activities by arbitrageurs, either before or after the reorganization, would not create a continuity of interest problem, since arbitrage activities are not normally a part of the overall plan of reorganization.

Under the second approach, the consequences of arbitrage activity would vary depending on the type of reorganization. With the Type A reorganization, there could be up to fifty percent share turnover; with Type B, there could be none; ${ }^{201}$ and with Type $\mathrm{C}$, there could be up to twenty percent. ${ }^{202}$ Although it may be illogical to have the rules on share turnover depend on the type of reorganization employed, straight logic has never been a long suit in this field.

The third approach, which is probably the approach that the Service will follow, yields a more reasonable result. It allows up to fifty percent share turnover after (and presumably also before) the reorganization, regardless of the type of reorganization. As pointed out above, this is the approach that the Preliminary Report seems to assume. If this approach is taken, however, then the committee staff's concern about the activities of arbitrageurs seems misplaced. The data suggest

198 IRS Private Letter Ruling No. 7926032 (Mar. 28, 1979) (available July 1, 1985, on WESTLAW, FTX-WD database).

${ }_{187}$ For a brief description of this type of reorganization, see infra text following note 298.

${ }^{198}$ See I.R.C. § 368(a)(2)(E)(ii), (c) (1982 \& West Supp. 1985).

109 See IRS Private Letter Ruling No. 7926032, supra note 196.

200 See Rev. Proc. 77-37, § 3.02, 1977-2 C.B. 568, 569.

201 See supra text accompanying and following note 195.

202 See I.R.C. § 368(a)(2)(B)(iii) (1982). 
that, although the activities of arbitrageurs are widely publicized from time to time, ${ }^{203}$ arbitrageurs rarely acquire more than thirty percent of a target company's stock. ${ }^{204}$ Indeed, their proportional ownership may be considerably lower in extremely large takeovers, in which institutions tend to have major holdings. ${ }^{205}$ Thus, under the third approach, Congress would not need to fashion new legislation dealing with arbitrage activity: the activities of arbitrageurs would rarely rise to the level necessary to destroy continuity of interest.

\section{iii. Use of the Parent's Stock-The Groman Doctrine}

If a corporation wishes to acquire another corporation tax free using one of the three basic acquisitive techniques, it may wish to give stock of its controlling parent as consideration, instead of its own stock. Would this qualify as good consideration for continuity of interest purposes? In the leading case on this question of remote continuity, the

${ }^{203}$ See, e.g., Dorfman, Gambling on Certainties, Forbes, May 24, 1982, at 172; Welles, Inside the Arbitrage Game, InSTITUTIONAL InvesTor, Aug. 1981, at 41; Metz, Use of Inside Data in the Takeover Game Is Pervasive and Can Lead To Huge Profit, Wall St. J., Mar. 2, 1984, at 12, col. 1; Salomon May Gain About $\$ 5.6$ Million in Columbia Merger, Wall St. J., Apr. 13, 1982, at 40, col. 3; Goldman Sachs Sees Value of Interest in Outlet Co. Fall, Wall St. J., Feb. 2, 1982, at 52, col. 4; Noble, Playing the Game of Arbitrage, N.Y. Times, Sept. 20, 1981, § 3, at 14, col. 2.

${ }_{20}$ See Metz, supra note 203 , at 12 , col. 2 (indicating that $30 \%$ is generally the maximum proportion of shares of the target held by arbitrageurs).

${ }^{20 s}$ See, e.g., Metz, In Battle for Conoco, Takeover Speculators Can Do Little More than Watch the Action, Wall St. J., July 31, 1981, at 21, col. 4 (describing a major takeover battle in which arbitrageurs held only about $14 \%$ of the stock of the target, compared to $62 \%$ held by institutions and $24 \%$ held by individuals).

Tracing the ownership of stock for these purposes is not wholly free from difficulties. As a result of the Securities Acts Amendments of 1975, Pub. L. No. 94-29, 89 Stat. 97 (codified at 15 U.S.C. $\S \S 77-78,80(1980)$ ), which had as one of its goals the facilitation of a national market system for securities, see id. $\S 11(\mathrm{~A})(\mathrm{a})(1), 89$ Stat. at $111-12$, the proportion of stock certificates held by nominees has increased dramatically. Moreover, there may be two or more levels of nominees. For example, an individual owner of 100 shares of IBM stock may leave it to be held by and in the name of her broker. The broker, however, might not hold the certificates itself; it might leave them in the possession and name of one of the three securities depositories-The Depository Trust Company, the Midwest Securities Trust Company, or the Pacific Securities Depository Trust Company-that act as custodians of securities deposited by participating institutions for their own accounts or for the accounts of others. Moreover, many institutions, especially banks, participate in a depository through a correspondent relationship established with another institution-so-called "piggybacking." See SECURITIES AND EXCHANGe CoMmission, IMPROving COMMUNICATIONS BETWEEN ISSUers aNd Beneficial OWNers of Nominee Held Securities 6-8 (June 1982). Thus, ascertaining owners of the stock of a target in a takeover setting for purposes of calculating continuity of interest can involve the substantial task of penetrating nominee holder records. The IRS would have authority to undertake such an investigation through its administrative summons procedure. See I.R.C. $\S 7602$ (a) (1982). See generally D. PosIN, supra note 17, at 433-35 (describing IRS administrative procedures). 
Supreme Court surprisingly answered "no." In Groman v. Commissioner, ${ }^{208}$ the acquiring corporation received the assets of the target in exchange for consideration consisting of the acquiring corporation's nonvoting preferred stock, its parent's nonvoting preferred stock, and cash. ${ }^{207}$ The Supreme Court held that, although the transaction still constituted a reorganization under the applicable law of that time, the parent's stock could not be counted for continuity of interest purposes and was therefore taxable. ${ }^{208}$ In the companion case of Helvering $v$. Bashford, ${ }^{209}$ the Supreme Court reached the same conclusion on similar facts. ${ }^{210}$

These were two of the later decisions of the Brandeis wing of the Court, which tended to use whatever grounds it could to find taxability in reorganization cases. ${ }^{211}$ The Groman and Bashford cases appear indefensible from a doctrinal standpoint. If the stock of the acquiring corporation confers continuity of interest, then the stock of the parent of the acquiring corporation should also confer continuity, at least where, as in Groman, the parent owns $100 \%$ of the acquiring corporation.

The Groman-Bashford doctrine has since been modified by statute to allow the stock of the parent of the acquiring corporation to be used to qualify for continuity of interest purposes, but only if no stock of the acquiring corporation is used. ${ }^{212}$ Where stock of both the parent and the subsidiary is used, there can still be serious problems with meeting the continuity of interest requirements, and the transaction may not qualify for nonrecognition treatment. Thus, shades of GromanBashford still linger. ${ }^{213}$

${ }^{208} 302$ U.S. 82 (1937).

207 See id. at 83 . Of course, there was no question that the cash portion of the transaction was taxable. See id. at 85 .

208 See id. at 89-90.

209302 U.S. 454 (1938).

210 See id. at 458. In Bashford the parent directly acquired the stock of the targets, and then immediately transferred the stock to a newly formed subsidiary. See id. at 455-56.

211 See suipra text accompanying notes 39-79.

${ }_{212}$ See I.R.C. $\S 368(a)(2)(D)$ (1982).

213 The current law in this area can be described in a little more detail. In a Type $B$ reorganization, the stock of the parent may be used to satisfy the continuity of interest requirement. If it is so used, the stock of the subsidiary that is acquiring the assets may not be used at all, either to count for the continuity of interest requirement or as boot, inasmuch as the statute requires that "solely" voting stock of the parent may be used as consideration in the transaction. See I.R.C. $\$ 368$ (a)(1)(B) (1982).

In a Type $C$ reorganization, the stock of the parent may be used to satisfy the continuity of interest requirement. If it is so used, the stock of the subsidiary that is acquiring the assets may not be counted toward satisfying the continuity of interest requirement. In this circumstance, the stock of the acquiring corporation would be considered as boot in the transaction, which could constitute up to $20 \%$ of the consideration. See I.R.C. $\S 368(a)(1)(C),(a)(2)(B)(1982)$. 
It appears that the major consequence of the Groman and Bashford cases is to help make the reorganization provisions optional in their application. By using consideration that includes stock of both parent and subsidiary (and the subsidiary may be formed just for this purpose), a transaction that is still entirely for stock can be rendered partially or completely taxable. ${ }^{214}$

\section{c. Critique}

As the discussion above has indicated, the continuity of interest doctrine, given its expression in the statute itself, the cases, and the regulations and rulings of the Treasury Department, is the glue that holds the reorganization field together. Despite the doctrine's importance, however, its treatment by the courts and the IRS has made very little sense.

The fundamental requirement of the continuity of interest doctrine is that the transferor of assets receive a substantial amount of equity as consideration. The receipt of the equity presumably leads the transferor to maintain a continuing proprietary interest in her transferred assets. Only then does she merit the holy grail of nontaxability. But only equity carries the essential genes for continuity of interest. Any equity, even nonvoting preferred stock, will do. ${ }^{215}$ At the same time it is equally clear from the case law that debt is not sufficient for this purpose. ${ }^{216}$ Even long-term bonds, secured by the property transferred, are

In a Type $A$ reorganization, stock of the parent may be used to satisfy the continuity of interest requirement. In that case, no stock of the acquiring corporation may be used without disqualifying the transaction entirely from reorganization status. See I.R.C. $\S 368(a)(2)$ (D) (1982). For further discussion of the Groman doctrine, see Lurie, Namorg-or Groman Reversed, 10 TAx L. REv. 119, 120-34 (1954).

${ }_{214}$ There might be several reasons why the parties would want to avoid treatment of the transaction as a tax-free reorganization. For example, the acquiring corporation may desire to step up the basis of the acquired assets for depreciation purposes. Similarly, the stockholders of the target corporation may have losses on holdings that they would like to reorganize.

Take the case, for example, where $P$ Corporation desires to effect what would be a Type A reorganization or statutory merger with $T$. For business or financial accounting reasons, the parties desire the consideration to be entirely stock, yet the parties also desire that the transaction be taxable. To avoid nontaxability, $P$ Corporation forms a subsidiary, $S$, and $T$ Corporation is merged into $S$ in exchange for consideration consisting of $70 \% P$ stock and $30 \% S$ stock. Under these conditions, the transaction is completely disqualified from reorganization treatment, despite being entirely for stock, and is taxable in full. See I.R.C. $§ 368(\mathrm{a})(2)(\mathrm{D})(1982)$.

${ }^{216}$ See, e.g., John A. Nelson Co. v. Helvering, 296 U.S. 374, 377 (1935) ("The owner of preferred stock is not without substantial interest in the affairs of the issuing corporation, although denied voting rights."). There is some talk that the IRS is considering not ruling on whether nonvoting preferred stock can be counted for continuity of interest purposes, but this position has not been formally announced or adopted.

${ }_{216}$ See, e.g., Pinellas, 287 U.S. at 470 (involving short-term purchase money 
inadequate. ${ }^{217}$ Drawing the distinction on these grounds simply makes no sense.

Consider a small automobile parts manufacturing firm, with one stockholder (an individual) $A$. The firm is acquired by General Motors solely in exchange for voting stock. Since $A$ receives only General Motors voting stock, she would meet the continuity of interest requirement, and the transaction would not be taxable to her. Yet $A$ would have far less than one percent of General Motors stock. In what sense can $A$ be said to be in any "continuity of proprietary interest" with her old automobile parts company? The fortunes of that little business are simply a drop in the bucket compared to the rest of the General Motors operations. $A$ is now just an investor who owns General Motors stock, an extremely liquid investment.

Suppose in the alternative that $A$ sold her business to individual $B$, who formed corporation $X$ for the purpose of making the purchase. $A$ receives as sole consideration fifteen-year bonds of $X$, secured by the assets of her transferred business. $B$ holds all the stock of $X$. Is $A$ not more personally concerned with the fortunes of her former business in this case than when she sold her business to General Motors? Are not the results of her holdings in the bonds much more intimately tied to the fortunes of her former business than to her ownership of less than one percent of General Motors stock? Indeed, the bonds will fluctuate in value depending on the success or failure of $X$ 's business.

Moreover, it is undoubtedly much more difficult to sell the bonds of this closely held corporation than it is to sell the stock of General Motors-demonstrating yet another way in which the results of $A$ 's investment are inextricably tied to the fortunes of her old business. Where she owns General Motors stock, $A$ is but one phone call to her broker away from completely severing whatever infinitesimal connection she still has with her old automobile parts business. Yet under the continuity of interest doctrine, $A$ qualifies for nontaxability on her sale to General Motors, whereas in the second transaction $A$, not having any equity, does not have a continuity of proprietary interest, and the selling of her assets for $X$ Company bonds is undoubtedly taxable to her. ${ }^{218}$

notes).

217 See LeTulle, 308 U.S. at 421.

${ }^{218} C f$. Roebling v. Commissioner, 143 F.2d 810, 813-14 (3d Cir. 1944). In Roebling, the taxpayer, pursuant to an "agreement of merger," exchanged stock in a public utility on which he received dividends derived from the rental of the utility's property, payable at a fixed eight percent rate. $I d$. at 811 . On the merger of the utility into another utility, taxpayer received 100-year bonds with a fixed eight percent return and was therefore held not to meet the continuity of interest requirement, despite the fact 
These anomalous results-occurring regardless of whether the transaction is structured as a merger, a stock-for-stock acquisition, or a stock-for-assets acquisition-grow out of the faulty steps taken in the early cases. In the first two cases, Cortland Specialty ${ }^{219}$ and Pinellas, ${ }^{220}$ no continuity of interest was found. In both cases it was argued that the transaction was within the literal terms of the reorganization statute. ${ }^{221}$ Nevertheless, it was reasonable for the Second Circuit and the Supreme Court to conclude that the transactions were basically sales, since the consideration involved consisted of short-term notes, ${ }^{222}$ a type of consideration clearly not within the contemplation of the nonrecognition provisions of the statute. Unfortunately, neither court rested its holding on a simple factual analysis. Rather, both courts used reasoning that came, thereafter, to be known as the continuity of interest doctrine. It is significant that in neither of these cases was it suggested that equity as consideration was the necessary and sufficient condition to qualify for nonrecognition.

The focus of subsequent decisions came to be not on whether the facts of the case demonstrated that the taxpayer had in effect sold out her business, but rather on whether there was a "continuity of interest." With the decisions in the subsequent cases of Minnesota Tea, ${ }^{223}$ Nelson, ${ }^{224}$ Watts, ${ }^{225}$ and finally LeTulle, ${ }^{226}$ the test became formalistic. The test was not whether the transaction on its facts looked like a sale, but rather whether there was a certain minimum amount of equity present in the consideration.

The continuity of interest doctrine therefore does not lead to reasonable results. It defies logic not to tax one who sells a small business to General Motors for less than one percent of General Motors stock but, instead, to tax one who sells a small business to a small company and receives long-term bonds secured by the assets. Notwithstanding the illogic of the doctrine, it has held the law of this field together for more than fifty years, and it may not be easy to eradicate. ${ }^{227}$

that his economic position was virtually unchanged. See $i d$.

210 See supra text accompanying notes 118-21.

220 See supra text accompanying notes 122-38.

221 See Pinellas, 287 U.S. at 467-68; Cortland Specialty, 60 F.2d at 939.

222 See Pinellas, 287 U.S. at 464; Cortland Specialty, 60 F.2d at 938.

223 See supra text accompanying notes 139-45.

226 See supra text accompanying notes 146-51.

225 See supra text accompanying notes 152-55.

228 See supra text accompanying notes 156-58.

227 See infra text accompanying notes 388-95. 


\section{d. Recent Development: The Paulsen Case}

Despite theoretical and policy infirmities, the continuity of interest doctrine, as developed by the early Supreme Court cases, has appeared to be a reasonably predictable test for ascertaining the taxability of corporate acquisitions. Thus, it was surprising that the recent Supreme Court case of Paulsen $v$. Commissioner ${ }^{228}$ presented such substantial difficulties.

Paulsen, at first glance, appears to be a case of limited significance to continuity of interest theory, since it involves the specialized concerns raised in connection with the merger of savings and loan associations. ${ }^{229}$ However, the Court's approach in Paulsen may have opened a Pandora's box of problems in the continuity of interest area with respect to hybrid securities. Paulsen is therefore a case of great consequence for this field and merits examination.

The Paulsens owned 17,459 shares of guaranty stock in the Commerce Savings and Loan Association, a state-chartered institution. ${ }^{230}$ As a result of the merger of Commerce into Citizens Federal Savings and Loan Association, a federally chartered mutual savings and loan association that was not authorized to issue capital stock, ${ }^{231}$ the Paulsens exchanged their stock in Commerce for passbook savings accounts and time certificates of deposit in Citizens. ${ }^{232}$ The Paulsens did not report their gain of approximately $\$ 153,000$ on the transaction because they believed it was a tax-free reorganization. ${ }^{233}$ The Court found that, although the transaction met the literal terms of the statute, ${ }^{234}$ the transaction was nonetheless taxable, because the continuity of interest test was not satisfied. ${ }^{235}$

Upon superficial examination, the receipt of passbook savings accounts and time certificates of deposit does not appear to satisfy the continuity of interest test, since these items are cash equivalents. Nevertheless, as Justice O'Connor noted in her dissent in Paulsen, all courts that had previously considered similar transactions had found that a

228105 S. Ct. 627 (1985), affg 716 F.2d 563 (9th Cir. 1983).

220 Mergers in this area present unique problems because of the inability of mutual savings and loan associations to issue stock. See Note, Reorganization Treatment of Acquisitions of Stock Savings and Loan Institutions by Mutual Savings and Loan Associations, 52 FordHAM L. REv. 1261, 1268-69 (1984).

230105 S. Ct. at 629.

231 Id. at 631.

232 Id. at 629.

$23 s$ Id.

234 Id. at 630 .

295 See id. at 632. 
continuity of interest existed. ${ }^{286}$ The reasoning was that, although the acquiring mutual savings and loan association could not issue stock, savings accounts and certificates of deposit had sufficient equity characteristics-such as the rights to vote and to receive undistributed proceeds upon liquidation-that their possession satisfied the continuity of interest requirement. $^{237}$

In finding that there was no continuity of interest, Justice Rehnquist, writing for the Court, undertook a technical analysis. He pointed out that the acquiring company, Citizens Federal, could not issue stock but rather could raise capital only "by accepting payments on savings accounts representing share interests in the association."238 These shares, which were divided into passbook accounts and certificates of deposit, were hybrid securities, containing both debt and equity characteristics. The equity characteristics that each share contained were the following: part ownership interest in the assets; a right to vote; receipt of dividends rather than interest; no right to a fixed return; and right to a pro rata distribution of remaining assets on dissolution. ${ }^{239}$ Rehnquist argued that the equity characteristics were "not as substantial as they appear[ed] on the surface."240

The part ownership interest that each share carried was not concentrated but rather was "spread over all of the depositors."241 Justice Rehnquist concluded that the equity interest of each shareholder in relation to the total value of the share was "much smaller than in a stock association." $" 242$

In the Court's view, the right to vote also was not significant. A shareholder was limited to 400 votes, and therefore any funds deposited in excess of $\$ 40,000$ did not confer the right to additional votes. Moreover, since each borrower was entitled to vote, the right to vote was further diluted each time a loan was made. Beyond that, depositors generally signed proxies giving management the right to vote their shares. ${ }^{243}$

The Paulsen opinion also denigrated the equity aspect of the right to receive dividends. The Court pointed out that in practice Citizens

${ }^{238} I d$. at 634.

${ }^{237}$ See, e.g., Capital Sav. \& Loan Ass'n v. United States, 607 F.2d 970, 975-76 (Ct. Cl. 1979); West Side Fed. Sav. \& Loan Ass'n v. United States, 494 F.2d 404, 411 (6th Cir. 1974); Everett v. United States, 448 F.2d 357, 360 (10th Cir. 1971), cited in Paulsen, 105 S. Ct. at 628.

$2 s 8105$ S. Ct. at 631.

239 Id.

$210 I d$.

241 Id.

242 Id.

243 Id. 
paid a fixed, preannounced dividend rate on all accounts, in order to be able to compete with other savings and loan associations and commercial banks. ${ }^{244}$ Moreover, the accounts were insured by the Federal Savings and Loan Insurance Corporation, and the dividends were treated by the Internal Revenue Code like interest on bank accounts rather than like dividends on stock. The dividends were deductible to Gitizens and did not qualify for the dividend exclusion under section 116 of the Code. ${ }^{245}$

In contrast, the Court saw the debt characteristics of the Citizens shares as substantial. The passbook accounts and certificates of deposit were not subordinated to the claims of outside creditors; the deposits, which could be withdrawn on thirty days notice, were not considered permanent contributions to capital. ${ }^{246}$ The Court also asserted that the face amount of the passbook accounts and certificates of deposit was $\$ 210,000$, and that no one would pay more than that for the taxpayers' shares. ${ }^{247}$ That being true, the value attributable to the equity characteristics of the shares was effectively zero, certainly far less than the substantial amounts of equity required in Minnesota Tea and Nelson. ${ }^{248}$ In light of this analysis, the Court concluded that the Paulsens had failed to meet the continuity of interest requirement; hence, the transaction was not a tax-free reorganization under section 368(a)(1)(A) of the Internal Revenue Code. ${ }^{249}$

Justice O'Connor's dissent took an equally technical approach. She agreed with the majority that the shares in Citizens Federal were hybrid securities with debt and equity characteristics but argued that the equity characteristics were substantial and that the shares thus satisfied the continuity of interest test. ${ }^{250}$ The Paulsens, in her view, had become equitable owners of Citizens, retaining all the usual rights of corporate stockholders. Thus, their interest carried more weight than that obtained by the nonvoting preferred stockholders in the Nelson case, in which the continuity of interest requirement had been

244 See id.

245 Id. at 632 (referencing the dividend exclusion set forth at I.R.C. $§ 116(b)(1)$ (1982)); see also Treas. Reg. § 1.116-1(d)(2)(ii) (1984) (providing that "mutual savings banks ... [and] loan associations" are ineligible for exclusion of their dividends).

${ }^{248}$ Paulsen, 105 S. Ct. at 632.

247 See id.

248 See id.

249 See id. at 634. The taxpayers also cited Tcherepnin v. Knight, 389 U.S. 332 (1967), in which mutual savings association shares "indistinguishable from Citizens" shares" were held to be securities. Paulsen, $105 \mathrm{~S}$. Ct. at 633-34. Justice Rehnquist dismissed this argument, however, noting that the holding in Tcherepnin resulted from a liberality in the interpretation of the securities laws "not warranted in construing the scope of the reorganization provisions." Id. at 634 .

${ }^{280}$ See 105 S. Ct. at 635-36 (O'Connor, J., dissenting). 
satisfied. ${ }^{251}$

Justice O'Connor took exception to the majority's overall method of valuing the debt and equity characteristics of the shares separately, pointing out that no court had ever taken this approach. ${ }^{252}$ In addition, O'Connor disputed the majority's denigration of the value of the equity characteristics of Citizens shares. She pointed out that dilution of voting power may occur in a corporation at any time that there is a new issue of stock ${ }^{253}$ and that proxy voting and preannounced fixed dividends are similarly characteristic of corporate shareholding. ${ }^{254}$ Finally, she suggested that the market value of the right to participate on liquidation and the deductibility of interest for tax purposes should be irrelevant to the characterization of the Gitizens shares for continuity of interest purposes. ${ }^{285}$

O'Connor concluded by pointing out that the majority opinion has ramifications beyond mutual associations. This was the first case in which the Court has had the opportunity to consider the use of hybrid instruments in reorganizations. Previously, the Court had decided whether continuity of interest was present simply on the basis of whether the consideration received was stock. If the Court is now to examine the actual exercise of the rights conferred by ownership of a particular security, predictability will be sacrificed. The test, O'Connor said, should be whether the instrument has the principal characteristics of equity ownership; if so, it should be treated as equity for continuity of interest purposes. ${ }^{256}$

The Paulsen decision reveals the shaky policy bases for the con-

251 See id. For a discussion of Nelson, see supra text accompanying notes 146-51.

252 See 105 S. Ct. at 636. Justice O'Connor noted that only Rev. Rul. 69-265, 1969-1 C.B. 109, supported the Court's fragmentation of an instrument into its debt and equity components and that "[a]pparently no court has ever relied on such a distinction with respect to a single instrument." Id. The ruling concerned a Type $\mathbf{C}$ reorganization, see infra text accompanying notes 287-94, in which stock that was given as consideration was convertible into stock of another corporation. The ruling posited certain circumstances in which the convertibility feature would be considered as separate "other" property, thereby invalidating the tax-free aspect of the reorganization.

263 See Paulsen, 105 S. Ct. at 637.

254 Id. O'Connor also noted that in the Nelson case, see supra notes $146-51$ and accompanying text, nonvoting preferred stock was found to confer continuity of interest.

${ }^{255}$ See id. at 637. Justice O'Connor emphasized the specific historical context of the provisions for deducting interest. See id. Her opinion also noted that the conclusion reached by the majority is inconsistent with the tax-deferred treatment accorded mergers between a stock association and a mutual association when the stock association is the survivor. See Rev. Rul. 69-3, 1969-1 C.B. 103 (merger of two mutual associations); Rev. Rul. 69-646, 1969-2 C.B. 54 (merger of mutual association into a stock association). Revenue Ruling 69-3 was noted by the majority in Paulsen, but was distinguished as involving an exchange of like-kind securities. See $105 \mathrm{~S}$. Ct. at 632.

${ }^{256}$ See 105 S. Ct. at 638. 
tinuity of interest doctrine. No valid theoretical or policy reasons have been given to justify the results reached in past continuity of interest cases. Without a cohesive policy underlying the continuity of interest doctrine, both the majority and dissenting opinions in Paulsen remain inevitably mired at the level of technical analysis.

The approach taken by the Court in Paulsen is troubling. In order to weigh the equity and debt components, the Court's analysis fragmented the mutual share involved. ${ }^{257}$ As Justice O'Connor noted, use of this approach with respect to hybrid securities outside the mutual associations area could undermine one of the few virtues of continuity of interest doctrine: predictability of result. ${ }^{258}$ This fragmentation could lead to a whole new generation of problems in the area of continuity of interest. It may be hoped that the IRS, the lower courts, and the Supreme Court limit the Paulsen approach to the specialized problems of mutual associations. ${ }^{250}$

\section{Substance over Form}

In addition to continuity of interest, the second great judicial doctrine to develop historically in the field of corporate reorganizations was the doctrine of substance over form. In the seminal case of Gregory v. Helvering, ${ }^{260}$ tax immortality was bestowed upon Mrs. Evelyn F. Gregory when she effected a maneuver the consequences of which continue to pervade every area of tax law. Despite its influence throughout tax law, the Gregory case holds perhaps its greatest sway in the reorganization field. ${ }^{261}$

Mrs. Gregory was the sole owner of the stock of United Mortgage Company. Among its other assets, United Mortgage owned 1000 shares of Monitor Securities Corporation. Mrs. Gregory wished to sell Monitor Securities for cash and to retain all of her other holdings. ${ }^{262}$ The most straightforward way of handling the transaction would have been to cause United Mortgage to declare a dividend of the Monitor Securi-

\footnotetext{
257 See id. at 631-33.

${ }^{238}$ See id. at 638 (O'Connor, J., dissenting).

258 See supra note 229.

280293 U.S. 465 (1935).
}

${ }^{281}$ See, e.g., Rice's Toyota World, Inc. v. Commissioner, 752 F.2d 89, 95 (1985) (citing Gregory in applying sham-transaction theory); Golden Nugget, Inc. v. Commissioner, 83 T.C. 28, 38 (1984) (citing Gregory in characterizing a transaction as "a mere device which put on the form of a corporate reorganization as a disguise for concealing its real character"); Smith v. Commissioner, 82 T.C. 705, 716 (1984) (citing Gregory in support of an analysis "in light of uncontroverted facts . . . not bound by the parties' labels"); Superior Coach of Fla., Inc. v. Commissioner, 80 T.C. 895, 905 (1983) (citing Gregory in its application of step-transaction doctrine).

262 See Gregory, 293 U.S. at 467. 
ties stock and then to sell the stock for cash. However, the distribution of the Monitor stock would have been taxable to Mrs. Gregory in full as a dividend, and paying tax on a dividend was an inconvenience she wished to avoid. ${ }^{263}$

One way to accomplish her goal was, of course, to liquidate United Mortgage. This would have given Mrs. Gregory a step-up in basis in her Monitor Securities stock to its fair market value at the price of only a capital gain. The subsequent sale of Monitor Securities would then have caused no further realization of gain, and Mrs. Gregory would have accomplished her goal.

However, Mrs. Gregory did not wish to liquidate United Mortgage. While it does not appear from the record why she did not wish to do so, some reasons may be easily inferred. From a tax standpoint, the liquidation of United Mortgage would have triggered a capital gains tax to Mrs. Gregory on Monitor Securities and on all the other assets of United Mortgage distributed to her. ${ }^{264}$ This could have resulted in a very substantial and, from Mrs. Gregory's point of view, very unnecessary tax liability. Moreover, there may well have been non-tax business reasons why Mrs. Gregory did not want to liquidate United Mortgage. Obviously the liquidation of a significant business, with its various contracts and ongoing relations with customers and suppliers, is not something to be undertaken lightly.

Thus Mrs. Gregory and her tax advisers decided to pursue the following scheme. They formed the Averill Corporation and caused United Mortgage to transfer to Averill all the stock of Monitor Securities. In return, Averill issued all of its stock to Mrs. Gregory. Six days later, Mrs. Gregory caused Averill to be liquidated. Under the reorganization statute in effect at that time-the predecessor of the spin-off provisions of the current statute ${ }^{268}$ - the liquidation was tax free to Mrs. Gregory. ${ }^{286}$ Mrs. Gregory therefore took a low carryover basis on the Monitor stock and enjoyed a capital gain on her immediate sale.

263 See id.

284 See I.R.C. § 331(a) (1982).

${ }^{208}$ The current restrictive rules in this area developed largely as a response to Mrs. Gregory's initial victory in the Tax Court. Gregory v. Commissioner, 27 B.T.A. 223 (1932). This decision was reversed by the Second Circuit, in an opinion by Judge Learned Hand. Helvering v. Gregory, 69 F.2d 809 (2d Cir. 1934), aff'd, 293 U.S. 465 (1935). The Gregory saga again illustrates the interplay that has been observed with respect to the early development of the continuity of interest doctrine. Congress jumped quickly to solve a perceived problem, which the courts ultimately also solved for cases predating the legislation. The net result is redundancy and an increased complexity in the relationship between the statute and case law. See H.R. REP. No. 704, 73d Cong., 2d Sess., 1939-1 C.B. (Part 2) 554, 563-65.

${ }_{\text {268 }}$ See Revenue Act of 1928, ch. 852, § 112(b)(3), 45 Stat. 791, 816 (1929) (current version at I.R.C. $\S 354-355$ (1982)). 
The Supreme Court concluded that the whole undertaking, though admittedly conducted according to the terms of the statute, was

[s]imply an operation having no business or corporate purpose-a mere device which put on the form of a corporate reorganization as a disguise for concealing its real character .... The whole undertaking ... was an elaborate and devious form of conveyance masquerading as a corporate reorganization .... The rule which excludes from consideration the motive of tax avoidance is not pertinent to the situation, because the transaction upon its face lies outside the plain intent of the statute. To hold otherwise would be to exalt artifice above reality and to deprive the statutory provision in question of all serious purpose. ${ }^{267}$

The importance of the Gregory decision far transcends its particular facts. Gregory was the birthplace of the doctrine that a transaction must have a business purpose to receive the benefits of the statute, and that in the absence of a business purpose the several steps of a transaction may be combined in order to reinterpret what actually happened. The Gregory approach has also come to be known as the doctrine of substance over form. ${ }^{268}$ Thus, under the aegis of Gregory, an elaborately planned and carefully carried out reorganization, which meticulously meets all the requirements of a complex statute, can still have its steps consolidated and be declared taxable because it fails to evince a business purpose.

The "step transaction" or "substance over form" doctrine now comes in three forms, as discussed above in connection with the $M c$ Donald's case. ${ }^{269}$ First, the courts may use the "end result" test. With this test the court looks at the beginning and end of the transaction to interpret what happened. Intermediate steps are ignored. ${ }^{270}$ The second test is the "interdependence" test. The court examines the various steps in a transaction to see if the taking of each step depends on the taking of the others. If the steps are found to be interdependent, then the court puts all the steps together to see what the tax consequences would be, rather than analyzing the tax consequences of each step indepen-

287 Gregory, 293 U.S. at 469-70.

${ }^{268}$ The doctrine of substance over form generally means that a transaction with tax-avoidance motives may be recast to reflect its economic substance, thereby causing the tax benefits to be lost. See B. BitTker \& J. Eustice, Federal Income TaxaTION of Corporations AND Shareholders $\mathbb{1}$ 14.51, at 127-28 (4th ed. 1979).

${ }^{289}$ See also Redding v. Commissioner, 630 F.2d 1169, 1175-78 (7th Cir. 1980). 270 Id. at 1175. 
dently. ${ }^{271}$ The final, and most restrictive form, is the "binding commitment" test, ${ }^{272}$ in which the several steps of a transaction can be put together only if the parties are contractually bound to move from one step to the next. ${ }^{273}$

The impact of Gregory has ranged far beyond the reorganization and corporate tax provisions to become part of the common law of federal taxation that courts may use to undermine a taxpayer's elaborate plans for tax avoidance. Gregory has been cited in over 1,000 federal cases decided since 1935. ${ }^{274}$ As important as Gregory has become elsewhere in the tax law, it remains a particularly brooding omnipresence in the reorganization area, and no sound tax planning in this area can take place without the Gregory doctrine receiving central consideration. ${ }^{278}$

From a policy standpoint, Gregory adds a substantial dash of irrationality to an already irrational body of law. Even after all the bases of the statute have been touched, and all the niceties of the continuity of interest doctrine have been observed, it is still possible for a court to look at the transaction and say that the whole edifice will be knocked down on the grounds of substance over form or lack of business purpose. The result could be that the transaction is taxed in a way that is completely different from the expectations of the parties, notwithstanding that they had followed the statute to the letter.

\section{Overview OF GURRENT LAW}

Having looked at the judicial and statutory evolution of the taxation of acquisitive reorganizations, it is useful now to summarize the current law. The agonizing process of development of the law has led to a system in which nonrecognition is accorded to acquisitive reorganizations, if certain consideration is given and other rules are followed. Concomitant with the nonrecognition provisions are substitute and carryover basis rules that preserve the untaxed gain or loss on the trans-

271 Id. at 1177.

272 Id. at 1178.

273 See McDonald's Restaurants v. Commissioner, 688 F.2d 520, 524-25 (1982); see also Mintz \& Plumb, Step Transactions in Corporate Reorganizations, 12 N.Y.U. Inst. ON Fed. Tax 247 (1954); Paul \& Zimet, Step Transactions, in Selected Studies in Federal Taxation 200 (2d ser. 1938).

${ }^{274}$ This figure is based on a July 1985 search of the FTX-CS and FTX-CS (OLD) databases on WESTLAW.

${ }_{275}$ See, e.g., Treas. Reg. § 1.368-1(b), (c), T.D. 7745, 1981-1 C.B. 134, 140; Treas. Reg. $\S 1.368-2(\mathrm{~g})(1960)$. These regulations in various ways reiterate the Gregory theme of a need for a business purpose and warn that arrangements that are mere devices to disguise a transaction's real character will not be treated as reorganizations. 
ferred assets.

The general outline of these provisions is as follows. To qualify for nonrecognition of gain with respect to both the corporations and the shareholders involved, the transaction must qualify as a reorganization, and the steps of the transaction must have been taken in pursuance of a plan of reorganization. ${ }^{278}$ Therefore, the definition of a reorganization is critical. There are five major types of acquisitive reorganizations defined in the statute. ${ }^{277}$ The definitions are keyed to the type of consideration that must be given, the amount of assets that must be acquired, and the formalities that must be followed. ${ }^{278}$ Moreover, the judicially imposed requirements relating to the continuity of interest and the requirement of a business purpose must be met for all these types of reorganizations, except where specifically modified by statute.

\section{A. Definition of Acquisitive Reorganizations}

\section{The Type A Reorganization}

The Type A reorganization is simply defined as "a statutory merger or consolidation."279 To qualify for treatment under this provision, the transaction must be a merger or consolidation "effected pursuant to the laws of the United States or a state or territory or the District of Columbia." ${ }^{280}$ Since the overwhelming number of corporations are organized under the laws of the states, most Type A transactions will be determined by reference to state law.

The statute imposes no requirements as to continuity of interest with respect to a Type A reorganization, and consequently the judicial and administrative rules discussed above will apply. Thus, at least fifty percent of the consideration given in a Type A reorganization must be equity to obtain a favorable advance ruling from the IRS. ${ }^{281}$ Those few taxpayers willing to hazard the transaction without the benefit of an advance ruling should have at least thirty-eight percent equity as con-

${ }^{278}$ See I.R.C. $\S \S 354,368$ (1982 \& West Supp. 1985); see generally Manning, In Pursuance of the Plan of Reorganization: The Scope of the Reorganization Provisions of the Internal Revenue Code, 72 HARv. L. REv. 881, 884 (1959).

${ }_{277}$ A sixth reorganization, the Type G reorganization, see I.R.C. § 368(a)(1)(G) (1982), involves a transfer by a corporation of all or part of its assets to another corporation in a title 11 (bankruptcy or reorganization) case. Since the shareholders in these cases are generally wiped out, special rules regarding continuity of interest are provided in these cases. An analysis of the Type $G$ reorganization is beyond the scope of this Article.

${ }^{278}$ See I.R.C. \& 368(a)(1)(A)-(F) (1982).

${ }^{279}$ I.R.C. $\S 368(\mathrm{a})(1)(\mathrm{A})(1982)$.

${ }^{280}$ Treas. Reg. $\S 1.368-2($ b)(1), T.D. 7422, 1976-2 C.B. $105,107$.

281 Rev. Proc. 77-37, 1977-2 G.B. 568, 569. 
sideration to stand a good chance in the courts. ${ }^{282}$ Additionally, there must be continuity of the business enterprise. ${ }^{283}$

\section{The Type B Reorganization}

The Type B reorganization is a transaction in which the acquiring corporation obtains a controlling amount of the stock of the acquired corporation. ${ }^{284}$ Under the statute, the consideration given by the acquiring corporation must be solely the acquiring corporation's own voting stock. ${ }^{288}$ Unlike the Type A reorganization, the Type B reorganization permits the acquired corporation to remain in existence, as a controlled subsidiary of the acquiring corporation. As with all these acquisitive reorganizations, there must be continuity of the business enterprise. ${ }^{286}$

The Type $B$ reorganization can be used, for example, in a takeover bid in which management of the acquired corporation is hostile to the transaction. Since the deal is made on a stock-for-stock basis, the acquiring corporation can make its appeal directly to the shareholders of the acquired corporation.

\section{The Type G Reorganization}

The Type $\mathrm{C}$ reorganization involves an asset acquisition; as such, it more closely resembles the Type A reorganization than the Type B. Indeed, the Type $\mathrm{C}$ reorganization is known in the trade as a "practical merger." "287 In a Type $\mathrm{C}$ reorganization the acquiring corporation must obtain "substantially all" of the assets ${ }^{288}$ of the acquired corporation in exchange for the voting stock of the acquiring corporation. ${ }^{289}$ Since "substantially all" of the assets of the acquired corporation must be obtained, the degree to which assets may be stripped from the acquired corporation before the reorganization (so-called "asset-tailoring") is limited in a Type $\mathrm{G}$ reorganization, unlike in Type A or Type B

282 See supra note 165

28s See supra note 168.

284 See I.R.C. § 368(a)(1)(B) (1982).

28s This section of the Code provides that the voting stock of the parent of the acquiring corporation may be used instead of the voting stock of the subsidiary corporation. See id.

${ }^{286}$ See supra note 168.

287 See American Potash \& Chem. Corp. v. United States, 399 F.2d 194, 201 (Ct. Cl. 1968 ).

${ }^{288}$ I.R.C. $\S 368(a)(1)(C)$ (1982). For advance ruling purposes the Service has indicated that "substantially all of the assets" means assets representing at least $90 \%$ of the fair market value of the net assets (assets minus liabilities) and $70 \%$ of the fair market value of the gross assets held by the corporation immediately before the transfer. Rev. Proc. 77-37, 1977-2 C.B. 568, 569.

${ }^{289}$ See I.R.C. \& $368(\mathrm{a})(1)(\mathrm{C})(1982)$. 
reorganizations. ${ }^{290}$

Unlike Type $B$, the Type $C$ reorganization allows the acquiring corporation to use property other than voting stock for up to twenty percent of the consideration. ${ }^{201}$ Generally, this other property will be cash, but it may be any other kind of tangible or intangible property or other securities of the acquiring corporation. In addition, the assumption of even substantial liabilities of the acquired corporation by the acquiring corporation is permitted. ${ }^{292}$ If the transaction involves property other than voting stock (for example, cash), then any assumption of liabilities is treated as other property and is counted along with it against the twenty percent limit on property other than voting stock. ${ }^{203}$

Once the acquisition of assets has been completed, the acquired corporation will still be in existence but will be essentially a holding company for the acquiring company's voting stock and any other consideration received. The acquired corporation must then be liquidated in pursuance of the plan of reorganization. ${ }^{294}$

200 Cf. Helvering v. Elkhorn Coal Co., 95 F.2d 732, 735 (4th Gir. 1937) (involving an attempt to transfer assets to two different companies under the predecessor to section 368(a)(1)(C)), cert. denied, 305 U.S. 605 (1938).

291 See I.R.C. \& 368(a)(2)(B) (1982).

292 See I.R.C. § 368(a)(1)(C) (1982).

293 See I.R.C. § 368(a)(2)(B) (1982).

194 See I.R.C. \& 368(a)(2)(G) (1982 \& West Supp. 1985). The rule that the acquired corporation must be liquidated in a Type $\mathbf{C}$ reorganization was added to the statute by section 63(a) of the Deficit Reduction Act of 1984, Pub. L. No. 98-369, 98 Stat. 494,583 . Under the Senate version of the bill, the liquidation had to take place within 12 months of the acquisition, but the Conference Committee version provided that the liquidation must be pursuant to the plan of reorganization, without specifying a particular time period. H.R. REP. No. 861, 98th Cong., 2d Sess. 845-46 (1984). Given this legislative history, it seems unlikely that the acquired corporation in a Type G reorganization would be able to stay alive much longer than 12 months.

The likely reason for requiring the liquidation was that keeping the acquired corporation alive presented tax avoidance possibilities. For example, the acquired corporation might be kept alive and its liquid assets used to engage at some future time in an active trade or business. Or the acquired corporation could remain alive and make taxfree distributions to shareholders under I.R.C. $\S \S 301$ (c)(1), 316(a) (1982), because the reorganization would have caused its earnings and profits to have been transferred to the acquiring corporation, pursuant to I.R.C. $\S 381$ (c)(2) (1982). See Rev. Rul. 73552, 1973-2 C.B. 116, 117; see also Staff of the Joint Comm. on Taxation, General Explanation of the Revenue Provisions of the Tax Reform Act of 1984, H.R. Doc. No. 4170, 98th Cong., 2d Sess. 189 (1984).

As is so often the case in trying to cure tax avoidance maneuvers, however, this change opens up other planning possibilities. Keeping the acquired corporation alive in a transaction that would otherwise qualify as a Type $\mathrm{C}$ reorganization now becomes a way to kill the Type $\mathbf{C}$ reorganization treatment of the transaction by taxpayers who want the transaction to be taxable (in order, for example, to step up the basis of the assets in the hands of the acquiring corporation for depreciation purposes). The requirement of a liquidation may be waived by the government. See I.R.C. $\S 368(\mathrm{a})(2)(\mathrm{G})(\mathrm{ii})(1982 \&$ West Supp. 1985). 


\section{The Forward Triangular Type A Reorganization}

The resolution of the issue presented in Groman $v$. Commissioner $^{295}$ and Helvering $v$. Bashford ${ }^{296}$-whether an acquiring company's use of its parent's stock as consideration satisfies continuity of interest requirements-gave rise to two forms of triangular mergers. Governed by section 368(a)(2)(D) of the Internal Revenue Code, the forward triangular merger is in effect a Type A reorganization, except that the consideration paid for the assets acquired consists of stock of the acquiring corporation's parent. No stock of the acquiring corporation itself may be used. Since the statute does not specify what portion of the consideration must be stock of the parent, cash or other property may be used along with that stock, subject to the general administrative and judicial continuity of interest requirements. ${ }^{297}$ The statute does require that the acquiring company obtain substantially all of the acquired corporation's assets, thus limiting pre-reorganization asset tailoring. ${ }^{298}$

\section{The Reverse Triangular Type A Reorganization}

Also a product of the Groman-Bashford litigation and its statutory resolution is the reverse triangular merger. The pattern of the reverse triangular merger, set forth at section 368(a)(2)(E) of the Internal Revenue Code, is that the acquiring corporation merges into the acquired corporation and thereby disappears. The parent of the acquiring/disappearing corporation must come into control of the acquired corporation, and the former shareholders of the acquired corporation must surrender a controlling amount of their stock in exchange for voting stock of the controlling parent.

When the transaction has been completed, the reverse triangular reorganization closely resembles the Type $B$ reorganization, in that the acquired corporation remains alive, with its assets intact, under the control of a new parent. That being the case, the rule on the consideration that must be given to the shareholders of the acquired corporation is similar to the rule for consideration in a Type B reorganization: that at least eighty percent of the stock of the acquired corporation must be surrendered by its shareholders for voting stock in the controlling corporation. Thus, no more than twenty percent of the consideration may

205302 U.S. 82 (1937), discussed supra notes 206-14 and accompanying text.

${ }^{298} 302$ U.S. 454 (1938), discussed supra notes 209-14 and accompanying text. 118-68.

207 The continuity of interest doctrine is discussed supra text accompanying notes

${ }^{298}$ See supra text accompanying note 288. 
be cash or other nonqualifying property. ${ }^{299}$ The acquired corporation must continue to hold substantially all of its properties and substantially all of the properties of the disappearing corporation. ${ }^{300}$ This provision limits the acquiring firm's use of pre-reorganization asset tailoring.

\section{B. Overlap Problems}

An outstanding feature of this statutory scheme is the great amount of overlap existing among these definitions. Ultimately, all of the acquisitive reorganization patterns involve the acquisition of the assets of one corporation by another, whether the assets are held directly or indirectly through a subsidiary. It is apparent that a given transaction may satisfy more than one of the reorganization definitions simultaneously. This situation is significant due to the fact that the substance over form doctrine ${ }^{\mathbf{3 0 1}}$ is always available to recharacterize transactions. As discussed above, the requirements and the consequences of these types of reorganizations vary widely. Therefore, characterizing which type of transaction has occurred can be crucial to ascertaining whether or not the requirements for nontaxability have been met and ascertaining the ultimate consequences of the transaction.

To respond to this situation, Congress, the courts, and the IRS have fashioned ordering rules that determine which reorganization will be deemed to have occurred when the requirements of more than one definition have been satisfied. The statute itself contains only one such rule. Section $368(a)(2)(A)$ provides that when a transaction qualifies as both Type $\mathrm{C}$ and Type $\mathrm{D}$, it will be deemed to be Type $\mathrm{D}^{\mathbf{3 0 2}}$ Various

299 See I.R.C. $\S 368(a)(2)(E)(i i)$ (1982). The fact that some nonqualifying property can be used as consideration in the reverse triangular reorganization can make it an attractive alternative to the Type $B$ reorganization, where only voting stock may be used.

${ }^{800}$ See I.R.C. $\S 368(a)(2)(E)(i)(1982)$.

so1 See supra text accompanying notes $260-75$.

soz A Type D reorganization involves

a transfer by a corporation of all or part of its assets to another corporation if immediately after the transfer the transferor corporation, or one or more of its shareholders . . . or any combination thereof, is in control of the corporation to which the assets are transferred; but only if, in pursuance of the plan, stock or securities of the corporation to which the assets are transferred are distributed in a transaction which qualifies under section 354,355 , or 356 .

I.R.C. $\S 368(\mathrm{a})(1)(\mathrm{D})$ (1982). The Type D transaction, therefore, is not an acquisitive reorganization but rather a shift or division of ownership of the underlying assets. As indicated in the text, it may, however, overlap with a Type $\mathrm{C}$ reorganization in some cases.

As an example of the significance of the ordering rule described in the text, if the 
other ordering rules have been promulgated from time to time by the IRS and the courts. ${ }^{303}$ While these ordering rules increase the complexity of reorganization regulations, they are perhaps preferable to being faced with an overlap problem for which there is not an established treatment.

\section{Treatment of Corporations}

Once it is established that a transaction qualifies as a reorganization under the definitional rules, it is then possible to ascertain the tax consequences to the corporations involved in the reorganization. With respect to merger reorganizations-the Type $A$ and the forward and reverse triangular Type A reorganizations-the acquired corporation is never taxed on the transfer of its assets, regardless of the consideration received. In the Type $\mathbf{C}$ reorganization, a corporation whose assets are acquired will not be taxed unless it retains some assets to pay creditors. $^{304}$ With respect to stock acquisitions-Type B reorganiza-

assets transferred are subject to liabilities in excess of their basis, the tax consequences will differ depending on whether the transaction is characterized as a Type $\mathrm{C}$ or Type D reorganization. See I.R.C. § 357(c)(1)(B) (1982).

${ }^{303}$ See, e.g., Commissioner v. Dana, 103 F.2d 359 (3d Cir. 1939) (overlap between Type B and Type C reorganizations); Rev. Rul. 67-448, 1967-2 C.B. 144 (overlap of Type $B$ and reverse triangular reorganization), superseded by I.R.G. $\S 368(\mathrm{a})(2)$ (E) (1982); Rev. Rul. 57-276, 1957-1 C.B. 126 (overlap between Type A and Type $\mathrm{F}$ reorganizations).

There are no ordering rules for transactions that may qualify as a Type $A$ or a Type $C$ reorganization, or transactions that may qualify as a Type $A$ or a Type D reorganization.

sos Section 361(a) of the Internal Revenue Code provides that no gain or loss shall be recognized to the transferor corporation if it transfers property pursuant to the reorganization plan and receives solely stock or securities in return. Section 361(b) provides that, if the transferor receives as consideration not only stock or securities received tax free under subsection (a) but also other property or money, then that will trigger recognition of gain to the transferor, unless the transferor distributes the other property or money to its shareholders in pursuance of the plan of reorganization.

Clearly, all consideration is distributed to the shareholders in the Type A, the forward triangular Type A, and the reverse triangular Type A reorganizations, since the transferor corporation goes out of existence in those transactions.

In the Type $\mathbf{C}$ reorganization, the corporation whose assets are acquired will not be taxed if it receives only stock or securities of the acquiring corporation in exchange for its assets. I.R.C. $§ 361$ (a) (1982). If the acquired corporation receives other property or money in addition to the stock or securities of the acquiring corporation, then the acquired corporation will be taxed on the other property or money unless it distributes that other property or money in pursuance of the plan of reorganization. I.R.C. $\S 361(b)(1)$ (1982). To qualify as a Type $C$ reorganization, however, the acquired corporation must be liquidated in pursuance of the plan of reorganization under I.R.C. $\S 368(a)(2)(G)$ (1982 \& West Supp. 1985). See supra notes 287-94 and accompanying text. Therefore it would appear that the acquired corporation in a Type $\mathbf{C}$ reorganization would never have to recognize gain. However, the acquired corporation in a Type $\mathrm{C}$ reorganization might retain some of the cash it received from the acquiring corpora- 
tions-the question of recognition of gain by the acquired corporation does not arise, since it does not undergo a realizing event but simply has its stock ownership change hands.

The acquiring corporation is not taxed on the issuance of its stock $^{305}$ or bonds ${ }^{306}$ in any of these types of reorganizations. Of course it is not taxed on the payment of money. However, it would have to recognize gain on the use of appreciated property as part of the consideration, since as to the appreciated property the exchange would be a sale. ${ }^{307}$

\section{Treatment of Shareholders}

The shareholders whose tax treatment is in issue in an acquisitive reorganization are, of course, the shareholders of the acquired corporation. The shareholders of the acquiring corporation are not involved. Under all types of acquisitive reorganizations, the shareholders of the acquired corporation are surrendering their stock in exchange for stock of the acquiring corporation, ${ }^{308}$ money, and/or other property. If the shareholders of the acquired corporation receive only stock, they do not recognize any gain or loss. ${ }^{309}$ If, in addition to stock of the acquiring corporation, property other than stock, including debt securities, is re-

tion to pay creditors and distribute the rest of its assets to its shareholders in liquidation. In that event, it appears that the transaction would still qualify as a Type $\mathbf{C}$ reorganization in that the payment to creditors would constitute a "distribution" for purposes of I.R.C. § 368(a)(2)(G). See Staff of JoInt Comm. ON TaXation, 98TH Cong., 2D Sess., General Explanation of the Revenue Provisions of the Deficit Reduction ACT of 1984, at 190 (Comm. Print 1984). For purposes of I.R.C. \& 361(b), however, the acquired corporation would continue to recognize gain to the extent that any money or other property is not distributed to its shareholders (as opposed to its creditors) in pursuance of the plan of reorganization. Thus, as a planning matter, the acquired corporation would be well advised to transfer all of its liabilities to the acquiring corporation and let the acquiring corporation use the cash to pay the liabilities.

sos See I.R.C. $\S 1032$ (1982 \& West Supp. 1985). The nonrecognition rules of section 1032, unlike the other nonrecognition provisions discussed in connection with reorganizations, do not depend for their applicability on the existence of a reorganization. It is always true that a corporation does not recognize gain or loss on the issuance of its own stock. See also Proposed Treas. Reg. § 1.1032-2, 46 Fed. Reg. 112 (1981) (providing nonrecognition rules for the acquiring corporation in a triangular reorganization).

sos The acquiring corporation is of course not taxed on the issuance of bonds in connection with the reorganization, because the issuance of bonds, being a transaction in the nature of a loan, is not a realizing event.

s07 See International Freighting Corp. v. Commissioner, 135 F.2d 310, 313 (2d Cir. 1943).

308 In a reorganization, shareholders may also be exchanging their stock for that of the controlling parent.

s09 See I.R.C. $\S 354(\mathrm{a})(1)(1982)$. 
ceived in exchange for stock of the acquired corporation, that will trigger the recognition of the realized gain to the extent of the fair market value of the other property received. ${ }^{\mathbf{3 1 0}}$ If debt securities are received in exchange for debt securities surrendered, then no gain will be recognized as long as the principal amount of the debt securities received is equal to or less than the principal amount of the debt securities given up. ${ }^{311}$ If debt securities are received in exchange for debt securities, and the principal amount of the debt securities received is greater than the principal amount of the debt securities given up, then gain will be recognized to the extent of the fair market value of the excess of the principal amount of the debt securities received. ${ }^{312}$

If gain is recognized to shareholders under these rules, the gain will be treated as arising from the sale or exchange of the stock given up (generally giving rise to a capital gain), unless the gain is found to have the effect of a distribution of a dividend, in which case it will be taxed as a dividend. ${ }^{313}$ Determining whether a gain has the effect of the distribution of a dividend is ascertained under the redemption rules of section 302, although it is not settled whether those redemption rules are applied with reference to the acquired corporation or the acquiring corporation. $^{\text {s14 }}$

In a Type $A$ or Type $\mathbf{C}$ reorganization, the target corporation is likely to have liabilities, which may be transferred to the acquiring corporation. The tax treatment of the transfer of liabilities has proven troublesome. The general rule is that the transfer of a liability incident to a reorganization does not result in recognition of gain to the target. ${ }^{316}$ There are, however, exceptions. Gain is recognized if the taxpayer had a tax avoidance purpose ${ }^{\mathbf{3 1 6}}$ or generally if the aggregate liabilities are in excess of the aggregate basis of the property transferred. ${ }^{317}$ The transfer of liabilities is treated as money for basis

s10 See I.R.C. \$§ 354(a)(2)(A)(ii), (a)(3), 356(a)(1) (1982).

311 See I.R.C. \& 354(a)(1)-(2) (1982).

312 See I.R.G. §§ 354(a)(2)(A)(i), 356(a) (1982); see also Treas. Reg. § 1.356-3, T.D. 7616, 1979-1 C.B. 458 (illustrating the required calculation).

s1s See I.R.C. § 356(a)(2) (1982).

s34 Cf. Shimberg v. United States, 577 F.2d 283, 287-88 (5th Cir. 1978) (dividend equivalence tested with reference to the acquired corporation); Wright v. United States, 482 F.2d 600, 607 (8th Cir. 1973) (dividend equivalence tested with reference to the acquiring corporation); Rev. Rul. 75-83, 1975-1 C.B. 112, 113 (dividend equivalence tested with reference to acquired corporation). The Shimberg approach tends to be less favorable to taxpayers, because under Shimberg the cash received by shareholders of the acquired corporation in proportion to their stockholdings in the acquired corporation will be given dividend treatment.

s1s I.R.C. § 357(a) (1982).

s16 I.R.C. § 357(b) (1982).

s17 I.R.G. § 357(c) (1982). 
purposes, causing the basis of property received in exchange to go down, ${ }^{318}$ as discussed in the following section.

\section{E. Basis Rules}

The stock received by the shareholders of the acquired corporation $^{\mathbf{3 1 9}}$ will take the basis of the stock transferred, decreased by the amount of money and the fair market value of other property received and increased by the amount of gain recognized to the shareholders. ${ }^{320}$ The basis of the other property received is the fair market value of that property. ${ }^{\text {s21 }}$

The basis of property-whether assets or stock-received by the acquiring corporation takes a basis equal to the basis the property had in the hands of the transferor, increased by any gain recognized to the transferor. ${ }^{322}$

\section{F. Carryover of Tax Attributes}

In asset-acquisition reorganizations-Type A, Type $\mathrm{C}$, and the triangular reorganizations-the tax attributes of the acquired corporation, such as net operating losses, earnings, profits, and business credits, carry over to the acquiring corporation. ${ }^{323}$ Special rules reduce the extent to which the acquiring corporation may make use of the acquired corporation's net operating losses. ${ }^{\mathbf{3 2 4}}$

${ }^{818}$ I.R.C. § 358(d) (1982).

310 The rules described in the text also apply to the acquired corporation itself, in an asset acquisition, when it is in receipt of stock or other property in the reorganization. Inasmuch as the acquired corporation in an asset acquisition will be disappearing as part of the reorganization plan, the basis rules for the property it receives are not generally of great consequence. See supra notes 287-94 and accompanying text.

s20 I.R.C. \& 358(a)(1) (1982).

s21 See I.R.C. § 358(a)(2) (1982).

s22 See I.R.C. § 362(a) (1982); see also Proposed Treas. Reg. § 1.358-6, 46 Fed. Reg. 112 (1981) (providing analogous rules for the basis of assets acquired in a triangular reorganization).

${ }^{\text {s2s }}$ See I.R.C. \& 381(a)(2) (1982). This carryover of tax attributes also occurs with Type D, Type F, and Type G reorganizations, which are beyond the scope of this Article. The rule does not apply to the carryover of tax attributes in the Type B reorganization, since in that instance the acquired corporation remains in existence.

s24 See I.R.C. $§ 382$ (1982); see also Eustice, The Tax Reform Act of 1976: Loss Carryovers and Other Corporate Changes, 32 TAX L. REv. 113 (1977); Posin, Changes in the Taxation of Corporations Effected by the Tax Reform Act of 1976: Part II-Restrictions on Loss Carryovers, 4 J. CoRP. TAX. 299 (1978). The effective date of the new rules in this area, initially enacted in 1976, see Tax Reform Act of 1976, Pub. L. No. $94-455, \S 806$ (e), 90 Stat. 1520, 1598-99, have been postponed several times and recently were postponed again, until 1986, by section 62 of the Deficit Reduction Act of 1984, Pub. L. No. 98-369, 98 Stat. 494, 583. 


\section{Senate Finance Committee Staff Proposals for REFORM}

\section{A. Overview}

As the preceding discussion has indicated, the law in the area of the taxation of corporate acquisitions has evolved into an exceedingly complex set of rules. Therefore, it is not surprising that a number of proposals for reform have been developed over the years by the tax bar, the accounting profession, the Treasury Department, and congressional committee staffs as part of a larger overhaul of the entire system of corporate taxation. ${ }^{325}$ A major focus of this work is the excessive complexity of the present rules and the necessity for doing something about it, in order to prevent a breakdown of the self-assessment system. Much of the thinking that has been developed over the last decade or more in this area has been embodied in the proposals of the staff of the Senate Finance Committee, which issued its preliminary report on September $27,1983,{ }^{328}$ and its final report on May 20, 1985. ${ }^{327}$ Not surprisingly, a major touchstone of these proposals is simplifying the rules for taxing corporations. ${ }^{328}$

With respect to the taxation of acquisitive corporate reorganizations, the Final Report proposes a two-step process. ${ }^{328}$

32s See, e.g., American Law Institute, Federal Income Tax Project: Subchapter C (1980); Federal Tax Division of the American INSTITUTE OF Certified Public accountants, Taxation of the Formation and Combination of Business ENTERPRISEs (1979); ABA Committee on Corporate Stockholder Relations, Tax Section Recommendation No. 1981-5, 34 TAx LAw. 1386 (1981); Beghe, The American Law Institute Subchapter C Study: Acquisitions and Distributions, 33 Tax Law. 743 (1980); Committee on Tax Policy (1970-1971), Tax Section of the New York State Bar Association, A Report on Complexity and the Income Tax, 27 TAX L. Rev. 325 (1972) [hereinafter cited as Tax Policy Report]; Jacobs, Reorganizing the Reorganization Provisions, 35 TAx L. Rev. 415 (1980).

${ }_{320}$ Some of the analysis in this report has been discussed earlier in this Article. See supra notes 182-99 and accompanying text. See generally Faber, Taxation of Corporations and Shareholders: Premises of the Present System, 22 SAN DiEgo L. REv. 5 (1985); Ginsburg, Special Topics in the Acquisitions Area, 22 SAN DiEgo L. Rev. 159 (1985); LeDuc, Current Proposals to Restructure the Taxation of Corporate Acquisitions and Dispositions: Substance and Process, 22 SAN Dirgo L. Rev. 17 (1985); Thompson, A Comparison of the Merger and Acquisition Provisions of Present Law with the Provisions in the Senate Finance Committee's Draft Bill, 22 SAN Diego L. REV. 171 (1985).

327 Staff of Senate Comm. on Finance, 99th Cong., 1st Sess., Final RePort on The Subchapter C Revision Act of 1985, (Comm. Print 1985) [hereinafter cited as Final REPORT].

s28 See id. at 38.

s20 The discussion of these proposals is based on the Final Report. See id. at 5058 (summary of proposals); id. at 211-35, 237-39 (technical explanation); id. at 79-132 (proposed statutory language); see also Preliminary RePORT, supra note 182, at 5564 (summary of proposals). 


\section{Qualified Acquisition}

As a first step, the transaction must meet the requirements for treatment as a "qualified acquisition." A "qualified acquisition" is either a "qualified stock acquisition" or a "qualified asset acquisition" as defined by a proposed new section 364 of the Internal Revenue Code. ${ }^{330}$

A qualified stock acquisition is defined as any transaction or series of transactions during a twelve-month acquisition period ${ }^{\mathbf{3 3 1}}$ in which one corporation acquires stock representing control of another corporation. ${ }^{332}$ This transaction approximates a Type B reorganization, with the addition of the twelve-month time limitation. ${ }^{\text {s3s }}$

A qualified asset acquisition means (1) any statutory merger or consolidation, or (2) any other transaction in which one corporation acquires at least seventy percent of the gross fair market value and at least ninety percent of the net fair market value of the assets of another corporation, and the transferor corporation distributes, within twelve months of the acquisition date, all of its remaining assets (other than assets retained to meet claims) to its shareholders or creditors. ${ }^{34}$ These transactions approximate Type $\mathrm{A}$ and Type $\mathrm{C}$ reorganizations under present law. ${ }^{335}$

Certain tax consequences flow from a finding that a qualified acquisition has occurred. The proposals introduce explicit electivity into the system by treating all qualified acquisitions as "carryover basis acquisitions," unless an election for treatment as a "cost basis acquisition" is made. ${ }^{336}$

\section{a. Carryover Basis Acquisitions}

The immediate income consequence of a carryover basis acquisition is that no gain or loss is recognized by the target corporation. ${ }^{337}$ The particular consequences for the basis of the acquiring corporation in the target corporation depend on whether the transaction is treated as a qualified asset acquisition or a qualified stock acquisition.

sso See Final RePORT, supra note 327, at 112.

ss1 This period is defined as the " 12 month period beginning with the date of the first acquisition of stock . . . involved in the qualified stock acquisition." Id. at 127. ss2 Id. at $112-13$.

s3s For a description of the Type B reorganization, see supra text accompanying notes 284-86.

ss4 Final RePORT, supra note 327, at 113.

sas See supra notes $279-83$ \& $287-94$ and accompanying text.

s36 See FINAL REPORT, supra note 327, at 117.

s37 See id. at 106. 
i. Qualified Asset Acquisitions

If the transaction is a qualified asset acquisition, the acquiring corporation takes the same basis in the assets acquired as the assets had in the hands of the target corporation. ${ }^{\mathbf{3 8}}$ The same rule applies to asset acquisitions-Type $\mathrm{A}$ and Type $\mathrm{G}$ reorganizations-under present law. ${ }^{339}$

\section{ii. Qualified Stock Acquisitions}

If the transaction is a qualified stock acquisition, the proposed rules provide an approach different from that used for stock acquisitions (Type B reorganizations) under present law. The current rule requires that the acquiring corporation take a basis of the target subsidiary's stock that is the same as the basis in the hands of the target's former shareholders. ${ }^{340}$ Under proposed new section 1020 of the Internal Revenue Code, the basis of the target's stock in the hands of the acquiring corporation is tied to the basis of the assets of the target in the target's hands. ${ }^{341}$ The purpose of this approach is to eliminate "many of the discontinuities under current law" between transactions involving assets and those involving stock of an acquired subsidiary. ${ }^{\mathbf{3 4 2}}$

Section 1020 implements this approach with a technical provision requiring that the "net inside basis"-the asset basis reduced by the issue price of any outstanding liabilities of the target assumed by the acquiror- ${ }^{343}$ be increased in the amount by which the cost of the stock received exceeds the net inside basis (or decreased by the amount the cost of the stock is less than the net inside basis). ${ }^{344}$ This "premium" or "discount" correction will cease to be made three years after the acquisition. ${ }^{345}$ During the initial three-year period, however, the provision in effect uses a cost basis for the stock, instead of a carryover basis, despite the fact that the transaction is a carryover basis acquisition. ${ }^{346}$

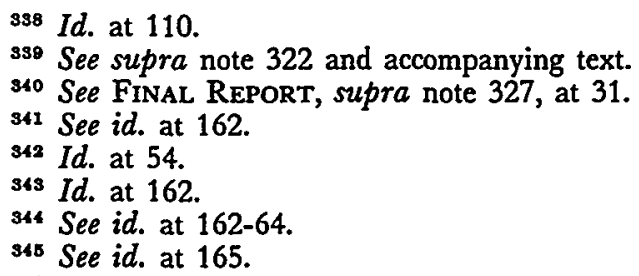

s39 See supra note 322 and accompanying text.

s4o See FINAL REPORT, supra note 327, at 31.

s41 See id. at 162.

342 Id. at 54.

s43 Id. at 162 .

s44 See id. at $162-64$.

s4s See id. at 165 .

346 Although not explicitly stated by the Final Report, the reason for this proposed rule may be the now-familiar problem identified in Kimbell-Diamond Milling Co. v. Commissioner, 14 T.C. 74, affd per curiam, 187 F.2d 718 (5th Cir. 1950), cert. denied, 342 U.S. 827 (1951). The Kimbell-Diamond problem has proven to be surprisingly difficult to deal with statutorily, and its history is perhaps instructive in this era of "tax reform" and "simplification."

Kimbell-Diamond involved a corporation that bought control of a company owning 


\section{b. Cost Basis Acquisitions}

If a cost basis acquisition is elected, the treatment of the transaction will depend on whether it is a qualified asset acquisition or a qualified stock acquisition.

If the transaction is a qualified asset acquisition, the target corporation recognizes gain or loss, and the acquiring corporation obtains a cost (usually "stepped-up") basis in the assets acquired, ${ }^{\mathbf{3 4 7}}$ determined under present I.R.C. $\S 1012 .{ }^{348}$

If the transaction is a qualified stock acquisition, the target corporation will recognize gain or loss on its assets-notwithstanding that the target remains in existence and its assets have not been transferred to the acquiring corporation. ${ }^{349}$ The basis of the target company stock in the hands of the acquiring corporation is the cost of that stock to the acquiring corporation. ${ }^{350}$

assets whose basis was much higher than their fair market value. The acquiring corporation then liquidated the target company and took a carryover basis in the target's assets, under section 113(a)(15) of the 1939 Code, predecessor to the present I.R.C. $\S 334(b)(1)$ (1982). Thus, the parent in effect had purchased high-basis assets for a low price, and it could then use that high basis for depreciation or for a deductible loss on a subsequent sale. The court in Kimbell-Diamond held on substance-over-form grounds that this maneuver was not effective. See 14 T.C. at 80 (noting that the minutes of the acquiring corporation evidenced a clear intent to liquidate the target company immediately after acquisition). Thus, the acquiring corporation was required to take the cost of the stock that it surrendered on the liquidation as its basis for the assets acquired.

Congress, however, was not content to let the issue be resolved by a judicial determination of intent. In 1954 it enacted a provision-codified as I.R.C. $\S 334(\mathrm{~b})(2)$ - that set forth objective criteria for evaluating various forms of the Kimbell-Diamond maneuver. See Internal Revenue Code of 1954, Pub. L. No. 591, $\S 334$, 68A Stat. 1, 104-06.

Section 334(b)(2) proved inadequate to deal with the various tax planning maneuvers that developed around it, however. Congress therefore repealed it and enacted in its place a provision codified at I.R.C. $\S 338$ (1982 \& West Supp. 1985). See Internal Revenue Code of 1954, Pub. L. No. 97-248, § 338, 96 Stat. 324, 485-90 (1982). Section 338, however, has proven to be an extremely complex provision. See, e.g., Ward, The TEFRA Amendments to Subchapter C: Corporate Distributions and Acquisitions, 8 J. CoRp. L. 277, 308-35 (1983).

If the new proposed section 1020 is enacted, section 338 would make an unusually rapid exit out the revolving door of tax reform. Given its complexity, however, this exit may be well deserved. In retrospect, Congress might have been better off to leave the Kimbell-Diamond problem in the hands of the courts, which had, some thirty-five years ago, developed a reasonably effective answer to the problem.

347 FINAL REPORT, supra note 327, at 106-08.

348 See id. at 223 . Although, in general, acquiring corporations elect to apply a cost basis, elections of a carryover basis may be made with respect to goodwill and certain other intangibles. See id. at 51 .

s49 See $i d$. at 106-07.

sso See I.R.C. § 1012 (1982). For a general discussion of the valuation of the stock given up in this type of transaction, see Porter, The Cost Basis of Property Acquired by Issuing Stock, 27 TAx LAW. 279 (1974). 


\section{Shareholder Treatment}

Once it has been determined that there has been a qualified acquisition, the treatment of shareholders is determined independently of the treatment of the corporations and of the election made at the corporate level. Rather, under the proposed amendments to I.R.C. $§ 354$, shareholders of the acquired corporation would be entitled to nonrecognition if they receive stock or securities of the acquiring corporation. ${ }^{361}$ Debt securities may be received tax free, however, only to the extent that the issue price of the debt securities received does not exceed the basis of the debt securities surrendered. ${ }^{\mathbf{5 5 2}}$

Receipt of "nonqualifying consideration"-that is, any consideration that cannot be received tax free-results in recognition of gain to the stockholder or security holder. ${ }^{353}$ The character of gain recognized under amended I.R.C. $\S 356$ would be determined by the section 302 redemption rules, making reference to the acquiring corporation. ${ }^{354}$

\section{B. Criticism}

\section{Complexity}

The relatively brief discussion above does not begin to describe the variety of complex technical rules that is part of the new legislation proposed by the Final Report. Indeed, there are 130 pages (double spaced) of new statutory language proposed by the Final Report as an overhaul of subchapter G. ${ }^{\text {s5s }}$ The staff of the Senate Finance Committee and their advisers may be commended for the high level of technical competence evident in this material. But it may be questioned whether the broader goals of the staff's efforts have been achieved in their specific proposals for reform.

One of the major reasons for proposing change in this area was to

ssi See Final RePORT, supra note 327 , at 83 . This consideration could include stock or securities of an affiliate of the acquiring corporation, see $i d$. at 52, thereby loosening the shackles of the codified Groman-Bashford doctrine. See supra text accompanying notes 206-14.

382 These proposals are roughly comparable to the present law, see supra notes 311-12 and accompanying text, except that the proposals, by focusing on the basis of the debt securities surrendered, contemplate the use of the time value of money to ascertain the amount of taxable boot on the receipt of debt securities. See FiNAL REPORT, supra note 327 , at 44 .

sss See Final REPORT, supra note 327, at 94.

sst See id. at 97. Thus, the approach of Wright v. United States, 482 F.2d 600, 607-08 (8th Cir. 1973), see supra note 314, would be followed, and the approach of Shimberg v. United States, 577 F.2d 283, 287-88 (5th Cir. 1978), supra note 314, would be rejected in this area. See Final REPORT, supra note 327, at 217.

sss Final REPORT, supra note 327, at 79-208. 
reduce complexity. ${ }^{358}$ With 130 pages of new statutory material, the proposals represent something less than a ringing success in this effort. $^{\text {357 }}$

One goal of these reforms was to change the taxation of corporate acquisitions from a system of transactional electivity-in which taxpayers manipulate the type of consideration received, the formation of subsidiaries, and other elements of the transaction ${ }^{358}$ in order to achieve desired tax results-to a system of explicit electivity, in which taxpayers could simply check off a form and elect the particular tax treatment they desire. ${ }^{369}$ At first it appears that this goal has been achieved: once there has been a qualified acquisition, the parties may elect a cost basis acquisition or a carryover basis acquisition. ${ }^{360}$ However, taxpayers have to jump through some pretty strict transactional hoops in order to achieve a qualified acquisition. ${ }^{\mathbf{3 6 1}}$ They may choose to jump through those hoops or not, depending on whether they wish to get into the elective system or avoid it. Thus transactional electivity is still present in the system.

The entire elective system can also be upended by taxpayer transactions subsequent to an election. For example, suppose the parties engage in a transaction in which the acquiring corporation acquires over seventy percent of the gross fair market value and over ninety percent of the net fair market value of the assets of the target. This transaction would constitute a qualified acquisition. ${ }^{362}$ The parties do not elect a cost basis acquisition, and the transaction will therefore be treated as a carryover basis acquisition. ${ }^{363}$ Suppose, however, that the target corporation does not distribute all of its assets within the required twelve-

356 See id. at 38.

ssz As just one example, consider the new I.R.C. $\S 1020$, see supra text accompanying note 341, which determines the basis of a target's stock in the hands of an acquiring corporation in a qualified stock acquisition. Under this provision, when a corporation makes a qualified stock acquisition instead of a cost basis acquisition, the transaction will be treated as a carryover basis acquisition. As discussed above, the general theory of section 1020 keys the basis of the stock to the basis of the assets plus any premium or discount at the time of the acquisition to create a "carryover" basis. The new section includes technical rules for computing the acquiring corporation's basis where it has not purchased $100 \%$ of the target's stock. See FINAL REPORT, supra note 327, at 162-63. In addition, it includes a variety of technical rules for keeping track of premiums or discounts during sales by the target of some of its assets. See, e.g., id. at 163-65.

s58 See supra notes $279-300$ and accompanying text.

359 See FINAL REPORT, supra note 327, at 41.

360 See supra text accompanying note 336.

s61 See supra text accompanying notes 330-35.

sez See supra text accompanying note 334 .

s63 See supra text accompanying note 336. 
month period following the acquisition. ${ }^{364}$ The transaction will then belatedly be deemed unqualified, and twelve months after the fact it will have to be restructured as taxable, with a cost basis to the acquiring corporation.

Thus, the parties can wait for twelve months after the acquisition and see if they wish to fall out of tax-free carryover basis treatment, depending on their particular tax circumstances at that time. Admittedly, this maneuver can occur under present law, but the new proposals are supposed to be an improvement.

Moreover, there is an air of unreality about the provision for an explicit election of cost basis treatment. Taxable cost basis treatment is always available under the new rules if the parties simply fail to have a qualified asset acquisition. As pointed out above, one may intentionally fail to meet those requirements. Thus, parties who are clear that they want a cost basis, taxable transaction-for example, for purposes of stepping up the basis of the acquired assets for depreciation-may be best advised, depending on the tax consequences to the shareholder, simply to structure their transaction so that it fails to become a qualified acquisition, rather than to create a qualified acquisition and run the risk that the election for cost basis treatment will be filed improperly, causing them to be stuck with carryover basis treatment. Thus, few transactions would ever actually run the pattern of a qualified asset acquisition followed by a cost basis election.

It appears, therefore, that these proposals have not achieved their stated goals of creating a simple system that is explicitly elective.

\section{An Election in Tax Polarity}

Consider further the principle of an election. As pointed out above, ${ }^{385}$ if the two corporations are interested in a taxable, cost basis transaction, they will probably simply avoid having a qualifying acquisition. Thus, transactional electivity will continue to play a major role under these proposals.

But suppose the proposed rules were modified so that explicit election did dominate the field. For example, suppose a qualified acquisition would occur if the acquiring corporation obtained fifty-one percent of the stock or assets of the target within a five-year period. It would now be much more difficult to structure a corporate acquisition that would not be deemed a qualified acquisition. Most corporate acquisitions would therefore be drawn into the explicit elective system of the

3es See supra text accompanying notes 361-64. 
new rules.

This situation may not proceed, however, quite as smoothly as the proposed rules seem to contemplate. ${ }^{\mathbf{3 6 6}}$ The acquiring corporation and target company will generally disagree on whether they want a taxfree, carryover basis transaction or a taxable, cost basis transaction. ${ }^{36 z}$ They are, in the vernacular of the field, in tax polarity.

Under current law, there are also two fundamental options: at the corporate level the transaction may be taxable, or it may be a tax-free reorganization. If, for example, the deal is an acquisition of the assets of the target company in exchange for mostly cash and notes, it will be taxable. The target will have to pay taxes on the appreciation in value of its assets sold, and the assets in the hands of the acquiring corporation will have a stepped-up fair market value basis. If, instead, the parties choose to use a sufficient amount of stock in the transaction, it can be a nontaxable reorganization, with no tax to the target on the sale, and carryover basis for the assets in the hands of the acquiring corporation. $^{368}$

Thus, the new rules do not increase the presently existing tax polarity between the acquiring corporation and the target. Indeed, the new rules decrease the adversary relationship between the parties somewhat, in that the parties can now use the consideration they want and still elect their preferred tax result at the corporate level.

Such a liberalization of corporate tax rules may not be desirable in this era of federal budget deficits and decline in the share of tax revenues paid by corporations. ${ }^{369}$ Whatever the defects of the continuity of interest doctrine, it at least required the parties to use a substantial amount of equity to achieve nonrecognition treatment. Use of a sub-

s8B See FinAL REPORT, supra note 327, at 221-28.

367 In the most usual case-the acquisition of a target with appreciated assets-the acquiring corporation would want a taxable, cost-basis transaction, to step up the basis of the assets for depreciation purposes. The target corporation would want a tax-free, carryover basis transaction to eliminate tax to itself.

${ }^{368}$ See supra text accompanying notes $279-300$. If cash and notes are used, the target corporation can still avoid tax if it is prepared to liquidate under I.R.C. $\$ 337$ (1982). A similar analysis can be made for stock acquisitions. Under current law the parties may choose to include cash or notes in the deal and thus render the transaction taxable. In that event, the stock sale will be taxable to the shareholders, and the stock will have a cost basis in the hands of the acquiring corporation. In the alternative, the parties may choose to use only voting stock as consideration, in which case the transaction would not be taxable to the selling shareholders, and the stock would take a carryover basis in the hands of the acquiring corporation. See supra text accompanying notes 284-86.

s69 See A. Auerbach, Corporate Taxation in the United States 2 (1982) (Brookings Institution papers on economic activity) (detailing the drop in corporate tax collections from $28 \%$ of total revenues in the mid-1950's to about eight percent currently). 
stantial amount of equity may not always be convenient for the parties: the owners of the acquiring corporation may not wish to dilute their control by issuing additional stock, and the shareholders of the target may hesitate to take stock if it is not readily tradable. Removal of this inconvenience may significantly increase the number of corporate transactions eligible for nonrecognition treatment.

Under the Finance Committee staff proposals, the acquiring corporation will generally make the election. In the case of a qualified asset acquisition other than a statutory merger or consolidation, the election must also be made by the target corporation. ${ }^{\mathbf{3 7 0}}$ Although in many cases the election need only be filed by the acquiring corporation, as a practical matter both parties-including the shareholders of the target-would have to agree on such an important matter in order to consummate the deal. ${ }^{371}$

Under these circumstances this election will probably not be as easily chosen or innocuous a procedure as other elections of the Internal Revenue Code-such as the election to operate a corporation under subchapter $\mathrm{S},{ }^{\mathbf{3 7 2}}$ the election out of the installment method for reporting a deferred payment sale, ${ }^{373}$ and the election to exclude gain from the sale of a principal residence by a taxpayer who has reached age fiftyfive. ${ }^{374}$ Generally, the taxpayers involved in elections such as these will be in agreement as to whether the election should be made. In contrast, the election to make an acquisitive corporate reorganization taxable or not is an election that must be filed by two taxpayers whose interests on the matter are adverse.

s70 See Final REPORT, supra note 327, at 228.

s71 The Securities and Exchange Commission generally requires disclosure of relevant tax information to shareholders of corporations involved in mergers or acquisitions. See, e.g., Securities Exchange Act Rule 14a-9, 17 C.F.R. § 240.14a-9 (1985) (forbidding false or misleading statements in proxy statements); Securities Exchange Act Schedule 14A, Item 14, 17 C.F.R. § 240.14a-101 item 14 (1985) (requiring certain information in proxy statements); Securities Exchange Act Schedule 14D-1, Item 10(f), 17 C.F.R. \& 240-14d-100 item 10(f) (1985) (governing statements in connection with tender offers). For examples of the type of tax information typically disclosed in corporate acquisitions, see General Motors Corporation Proxy Statement, Sept. 21, 1984, at 40-44 (issued in connection with GMG's acquisition of Electronic Data Systems); Robin Acquisition Corp. Offer to Purchase for Cash Common Stock of Uniroyal Inc., Apr. 15, 1985, at 7-8.

s72 See I.R.G. § 1362 (1982 \& West Supp. 1985); see also B. BrTTKER \& J. EusTICE, supra note 268, at I 6.02 (discussing requirements corporations must satisfy to make an election under subchapter $S$ ).

s7s See I.R.C. \& 453(d) (1982); see also D. Posin, supra note 17, at 392-95 (using detailed examples to describe the installment method of reporting).

s74 See I.R.C. § 121 (1982); see also D. PosIN, supra note 17, at 167-68 (discussing the permanent exclusion of gain from a sale of residence by a person fifty-five years or older). 
Beyond these problems, the proposals contemplate that the election, if filed at all, could be filed up to nine months after the acquisition. ${ }^{\mathbf{3 7 5}}$ The parties might complicate matters further by filing inconsistent reports. One party could claim that a valid election had been made, while the other claimed the opposite, resulting in a conflict that might be resolvable only through litigation.

The situation also conjures up the possibility of a bizarre threecornered litigation in which the acquiring corporation and the acquired corporation's former shareholders disagree on whether a valid election has been filed, and the Service takes sides with one or the other, depending on which outcome will yield the most revenue. Indeed, the Service might litigate against both sides, in different jurisdictions, and perhaps obtain inconsistent results. ${ }^{378}$ This does not advance the cause of simplification.

As pointed out above, the proposed rules do not seem to create a system that would be explicitly elective in practice. ${ }^{377}$ The foregoing analysis has suggested that even if the proposed rules were modified to create an explicitly elective system, such a system would not work as smoothly as other elections in the Internal Revenue Code.

\section{Selective Asset Sales}

Another problem with the proposed rules is that the ability of corporations involved in an acquisition to elect basis treatment could lead to manipulations of the rules. For example, corporations may engage in the selective advance purchase of appreciated assets to gain a basis stepup in those particular assets, followed by an acquisition in which they elect no taxability and carryover basis for the balance of the assets. In an attempt to foreclose these maneuvers, the Final Report sets forth further rules regarding the election of cost or carryover basis. The rules

s78 See FinAl REPORT, supra note 327, at 232.

${ }^{378}$ It is ironic that one of the reasons given in support of the proposals in the Final Report is the elimination of inconsistent results-whipsaw-in the present law. Cf. King Enters. v. United States, 418 F.2d 511, 516 (Ct. Cl. 1969) (discussing differences in application of step transaction principles).

A lesson can be learned here from the whipsaw problem that arises on the sale of a sole proprietorship, where the parties must allocate the sale price among the various assets of the business for purposes of characterizing the gain or loss on each asset as capital or ordinary income. The parties are generally adverse on this matter, particularly on the question of allocating a portion of the sales price to good will or to a covenant not to compete. This tax polarity has led to substantial litigation after the fact, including cases of whipsaw. See D. Posin, supra note 17, at 261-62; Remarks by Philip R. Miller at Court of Claims Judicial Conference, October 14, 1971, on Whipsaw Problems in Tax Cases, 25 Tax Law. 193, 193 (1972).

s7z See supra text following note 364 . 
specify a two-year "consistency period," extending from one year before to one year after the acquisition date. Any asset separately acquired by the acquiring corporation during the consistency period must be treated consistently with the qualified acquisition (both carryover or both cost basis acquisitions). Failure to treat such transactions consistently results in mandatory cost basis treatment for the asset separately acquired and for the qualified acquisition. ${ }^{378}$

This rule might be circumvented if the target corporation drops the appreciated asset into a controlled subsidiary. When the acquiring corporation acquires the target, it may accomplish a selective step-up in asset basis by electing a carryover basis as to the target and a cost basis as to the subsidiary. ${ }^{370}$ The Final Report has sought to foreclose this maneuver by providing that the consistency period would apply not only to assets acquired directly from the target corporation but also to assets of the target obtained in a qualified asset or stock acquisition of an affiliate corporation of the target. ${ }^{380}$ Overall, the Final Report provides fifteen examples of how the consistency rules would operate to prevent avoidance maneuvers. ${ }^{381}$

It appears, however, that there are several problems with the rules establishing a consistency period. First, they are not strikingly simple, despite the fact that simplicity is supposed to be a major justification for these proposals. Second, they involve administrative difficulty in tracing what will, in some cases, be a great number of asset transfers during the consistency period. Third, they can be avoided by effecting transfers outside the two-year period, a potentially worthwhile endeavor for assets with a substantial unrealized gain or loss. Thus selective basis stepup is still possible. Fourth, the rules require additional clarification. For example, suppose an asset has moved from the target to an affiliate of the target during the consistency period and is then disposed of by the affiliate in a nonrecognition transaction. ${ }^{382}$ The taint of being a "hot" asset in this regard will have to be transferred to the asset received in the exchange, requiring additional technical rules. These rules could become quite complex if several assets and boot are involved in the exchange.

Finally, these rules have the problem that in many cases the tail can wag the dog in a most cumbersome fashion. Relatively small asset

378 See, e.g., Final RePort, supra note 327, at 228.

370 This pattern is possible under the proposed rules, which contemplate that elections will be made on a corporation-by-corporation basis. See id. at 228-33.

sso See id. at 230 (example viii).

s81 Id. at 229-30.

s82 See, e.g., I.R.C. $§ 1031$ (1982 \& West Supp. 1985) (governing like-kind exchanges). 
sales by the target to the acquiring corporation during the consistency period can trigger a large qualified acquisition to be treated as a cost basis acquisition instead of a carryover basis acquisition, contrary to the expectations of the parties. ${ }^{\mathbf{3 8}}$ There are some nightmarish problems here for the ill advised. ${ }^{384}$

\section{Entity Versus Aggregate}

Another unsettling aspect of these basis election proposals is that they start to look like the rules for the taxation of partnerships. ${ }^{385}$ One of the causes of the extreme complexity of partnership taxation is the conflict in subchapter $\mathrm{K}$ of the Internal Revenue Code between treating the partnership as an entity and penetrating the partnership form to treat it as an aggregate of assets. Some leading commentators have suggested that

[t]his blending of aggregate and entity concepts is one of the primary sources of uncertainty in the interpretation and application of Subchapter K. A wide variety of situations that are not squarely covered by the statute are susceptible to resolution in dramatically different ways, depending on whether effect is given to the entity or aggregate concept. The absence of a unifying entity or aggregate theme in the statute means that these situations must be resolved on an ad hoc basis, by reference to the way in which the statute applies the entity and aggregate concepts to related or analogous situations-a process which is difficult, tedious and uncertain. The resultant lack of predictability in the application of Subchapter $\mathrm{K}$ is exacerbated [sic] because the considerations which lead to the predominance of the entity or aggregate concept in one context may be only subtly different from those which give rise to the use of the opposing concept in another. ${ }^{386}$

While the limited basis elections involved in the Final Report do not begin to approach in complexity the various basis adjustments in the partnership area, these proposals are probably a step in the wrong direction. In the future, there may be additional basis adjustments or

s8s See Final REPORT, supra note 327, at 229-30.

s84 Regulations might provide some relief in this area. See id. at 229. However, regulations interpreting these already complex rules would put further demands on practitioners.

s85 See I.R.C. $\$ \S 732(d), 734,743,754$ (1982 \& West Supp. 1985).

s86 W. McKee, W. Nelson \& R. Whitmire, Federal Taxation of PartNERSHIPS AND PARTNERS 1-7 (1977). 
other proposals that may treat the corporation as an aggregate of assets rather than as an entity, further complicating the field of corporate taxation. Indeed, the current proposals already employ partnership lexicon in referring to "inside basis" and "outside basis" with respect to an asset owned by a corporation or the stock owned by its shareholders. ${ }^{387}$

\section{Continuity of Interest}

One would have hoped that such comprehensive proposals as these would have at least eliminated the continuity of interest doctrine as a touchstone for taxability. ${ }^{388}$ Unfortunately, some of the more irrational vestiges of this venerable doctrine still linger in the proposed rules for the taxation of shareholders. As pointed out above, the treatment of shareholders under the proposals would be ascertained independently of whether there was recognition of gain at the corporate level. ${ }^{389}$ Those shareholders who receive stock in exchange for their stock in the acquired corporation would be accorded nonrecognition of gain. ${ }^{390}$

This is not a particularly satisfactory result. For example, a shareholder whose small auto parts firm is taken over by General Motors in a transaction that would fit within a Type $\mathrm{C}$ reorganization under present law would under the proposals not be taxed on the receipt of General Motors stock, notwithstanding that she has a relatively liquid investment that has only an infinitesimal relation to her old business. There seems to be no reason to defer gain to this shareholder, who can easily sell some of the stock to pay the tax. The difference between the shareholder who receives General Motors stock and the shareholder who receives cash is inconsequential. By contrast, a shareholder who sells her small auto parts business to another small firm and receives, in exchange for her stock, debt of the new small firm, secured by her former assets, has taxable gain both under current law and these proposals. Thus, one of the more irrational aspects of the continuity of interest doctrine is carried forward in the Senate Finance Committee staff's proposals for reform. ${ }^{381}$

If one were writing on a clean slate, it would seem preferable, and more in accord with the policy and the early historical development of

387 This terminology is used in connection with new proposed section 1020 . See Final REPORT, supra note 327, at 237 . For use of this terminology with respect to the extremely complex basis calculations in the partnership area, see, for example, S. LIND, S. Schwarz, D. Lathrope \& J. Rosenberg, Fundamentals of Partnership TAXATION 40 (1985).

${ }^{388}$ See supra text accompanying notes $215-27$.

${ }^{380}$ See supra text accompanying note 351.

390 See FINAL REPORT, supta note 327, at 52.

so1 See supra notes 118-68 and accompanying text. 
the continuity of interest doctrine, to limit nonrecognition to those instances in which the shareholder receives stock or securities in a corporation that is not publicly traded in an established securities market. ${ }^{\mathbf{3 9 2}}$

In defense of the Final Report, however, it can be argued that it deals with the "May Kass effect." This alludes to Kass v. Commissioner, ${ }^{393}$ in which a minority shareholder, May B. Kass, received stock in a statutory merger and still was taxed because the other shareholders received so much cash that the continuity of interest was destroyed. ${ }^{394}$ Thus, May Kass was taxed although she received only stock and had no control over the transaction. Under the new proposals, May Kass would not be taxed.

However, the improvement here is not as significant as might first appear. Even under the new proposals, a minority shareholder is still a minority shareholder and not in control of whether her corporation is acquired. It is true that under the new proposals if a corporation is acquired and the minority shareholder receives stock, she will not be taxed, regardless of the consideration received by the other shareholders. However, a minority shareholder would be much less likely to receive stock under the new proposals. Stock would not be required to confer nontaxability at the corporate level; thus there is less incentive to issue stock in corporate acquisitions. Instead, more cash or bonds will probably be distributed to the shareholders, resulting in the future May Kasses being more likely to receive cash or bonds on which they will be taxed, with the entire matter still outside of their control. ${ }^{395}$

\section{Unforeseen Practitioner Ingenuity}

This is not the first time that comprehensive proposals have been promulgated to simplify and clarify all the problems of the law of taxation of corporate reorganizations. The review of the history of legislation in this area set forth earlier in this Article ${ }^{\mathbf{3 9 6}}$ does not, however,

382 To prevent the usual evasive techniques the rule should provide that nonrecognition will be accorded only if the firm whose stock or securities are received is not an affiliate of a firm whose stock is publicly traded on an established securities market.

s9s 60 T.C. 218 (1973), aff d mem., 491 F.2d 749 (3d Cir. 1974); see also supra note 165 (discussing Kass in greater detail).

39460 T.C. at 227.

s9s Under the new proposals, as under current law, if a shareholder gives up stock and receives only bonds back, she will be taxed in full on the receipt of the bonds. See FINAL REPOR', supra note 327 , at 52.

In any event, what was so bad about the May Kass effect? Ms. Kass presumably received capital gain on the exchange of her shares for new shares. If she does not like being subject to the vagaries' of stock market transactions beyond her control, she should not invest as a minority stockholder.

${ }^{388}$ See supra text accompanying notes 81-117. 
inspire confidence that these proposals will be successful. The previous legislative attempts have not accomplished these laudable goals and sometimes have even worsened the situation. The development of the law in this area is the result of continuing thrusts, counter-thrusts, and parries by practitioners, the IRS, Congress, and the courts. This continual conflict is not surprising, given the great tax stakes involved. Moreover, this process will probably not stop with the enactment of these proposals. This is in no way meant to denigrate the Senate Finance Committee staff and others in the profession who have worked to develop these proposals and their predecessors. It is, rather, more of a testimony to the brilliance of the tax bar. I do not doubt that should these proposals be enacted, the academic criticisms offered here will pale in comparison with the creative avoidance maneuvers generated by some of the leading lights in the profession: some of whom had a hand in developing the proposals. ${ }^{397}$

\section{Transition}

Notwithstanding the brilliance of the new tax planning that these proposals will undoubtedly elicit from some leading practitioners, there may be substantial problems for many tax practitioners in the transition to a major new set of corporate taxation rules. This issue should be viewed in the context of the rapid pace of change in the taxation field generally. The period from 1981 to 1984 has seen the enactment of three major pieces of tax legislation. ${ }^{398}$ This onslaught of change is perhaps as debilitating to the system as complexity. In this setting, the case for enacting the Senate Finance Committee staff's proposals would indeed have to be overpowering.

\section{GoNCLUSION}

The present system for taxing corporate reorganizations has evolved into an ungainly, complex body of law. In the early days of the development of this law, there were two theories of how these transactions should be taxed. One held that there should be just general, simple rules that the courts would interpret. The disadvantage of this theory was the lack of predictability of results. The other theory held that there should be a detailed statute covering all contingencies. The disad-

397 For a preview of some of the possible maneuvers on the new rules, see Ginsburg, supra note 326, and Thompson, supra note 326.

${ }^{398}$ Deficit Reduction Act of 1984, Pub. L. No. 98-369, 98 Stat. 494; Tax Equity and Fiscal Responsibility Act of 1982, Pub. L. No. 97-248, 96 Stat. 324; Economic Recovery Tax Act of 1981, Pub. L. No. 97-34, 95 Stat. 172. 
vantage of this view was that the statute would have to be extremely complex. Remarkably, the system has evolved to have the disadvantages of both theories. The web fair Penelope has spun does indeed ravel and unravel. . $^{399}$

This is not to suggest, however, that the present system should be abandoned. The present system is a fact of life and has been in place for decades.

It is in this light that the proposals of the Senate Finance Committee staff should be viewed. These proposals, doing away with much of the continuity of interest doctrine and creating an explicitly optional system, have much to commend them and appear at first blush to be simpler than the present system. This Article's criticisms of the proposals, however, demonstrate that this simplicity is illusory and that these proposals are actually much more complex than they appear. ${ }^{400}$ This

s98 HoMer, THe Odyssey 24 (W. Rouse ed. 1937) ("There she was all day long, working away at the great web; but at night she used to unravel it by torchlight.").

${ }^{100}$ A major discussion of alternative proposals to reform the tax law is beyond the scope of this Article. However, since this Article has criticized the proposals set forth in the Final Report, it seems inappropriate to conclude without offering some alternative speculations.

A major theme of those who criticize the American federal tax system-particularly, the system of corporate taxation-is the great complexity of the present law. It is said that complexity is so great a threat to the integrity of the tax system that simplification should be the overriding concern in effecting change. See, e.g., PRELIMINARY REPORT, supra note 182, at 1; Eustice, Tax Complexity and the Tax Practitioner, 8 TAX ADviser 27 (1977); Jacobs, supra note 325, at 415-17; Tax Policy Report, supra note 325 , at $328-31$.

There are two interrelated proposals for simplifying the corporate tax system and the tax system in general that seem to have merit: (1) to repeal the corporate tax; and (2) to repeal the favorable treatment of capital gains. Taken as a package, these proposals effect a dramatic simplification without generating any obvious ill effects on the equity of the system or on revenues.

Moreover, these proposals, taken as a package, may be relatively salable to the public. The repeal of the corporate tax may be seen by the public as a giveaway to the wealthier interests. The accuracy of that view is far from clear, inasmuch as the incidence of the corporate tax has not been established. See Klein, The Incidence of the Corporation Income Tax: A Lawyer's View of a Problem in Economics, 1965 Wis. L. Rev. 576; see also J. Pechman \& B. Okner, Who Bears the Tax Burden? (1974); Gordon, The Incidence of the Corporation Income Tax in U.S. Manufacturing, 1925-1962, 57 AM. EcoN. REv. 731 (1967). Making the package more palatable to the public is the view that the repeal of the favorable treatment of capital gains is something of a take-back from the wealthier interests. Similarly, those who are concerned that repealing the favorable treatment of capital gains would depress needed business investment could be met with the answer that the corporate tax was repealed.

The Senate Finance Committee staff stated that it simply "assumed that a corporate income tax would continue to be imposed," observing that "the Federal Government began collecting a corporate income tax even before the 16th Amendment authorized an individual income tax. Nor is there any indication that the repeal of the corporate income tax is imminent." PReliminary RePORT, supra note 182, at 4.

The suggestions to repeal both the corporate tax and the favorable treatment of capital gains are consistent with some of the ideas embodied in the recent Treasury 
complexity represents a serious problem for a set of proposals whose major rationale was simplification.

Moreover, it appears that the reasons for attempting to overhaul the system are open to question. The Preliminary Report states, for example, that substantial abuses are occurring in the current system. ${ }^{401}$ The Report refers to a number of problems created by the continuity of interest doctrine, relating to McDonald's Restaurants $v$. Commissioner, ${ }^{402}$ the treatment of arbitrageurs, and the use of holding companies to avoid the continuity of interest requirement in certain acquisitions. ${ }^{403}$ The McDonald's case and the treatment of arbitrageurs have been discussed above. ${ }^{404}$ The difficulties relating to the use of holding companies were occasioned by the Service's own misstep in a private letter ruling, ${ }^{405}$ which it cured in later rulings. ${ }^{106}$ It cannot seriously be argued that these relatively recent technical problems justify overhauling the entire system of taxing corporate acquisitions. Given the availability of the heavy artillery of Gregory $v$. Helvering, ${ }^{\mathbf{4 0 7}}$ cited in both holding company rulings noted above, ${ }^{408}$ it seems unlikely that any particularly egregious maneuver would last long.

Another reason given by the committee staff for overhauling the entire system is that the tax consequences of acquisitive corporate reorganizations that are economically similar can vary sharply, depending on the form used and the type of consideration employed. ${ }^{408}$ The new proposals, however, would also allow the tax consequences of acquisitive transactions that are economically similar to vary sharply, at the option of the parties. The difference between the current and proposed regimes is that under the latter the option is de jure while under the

Department report to the President (so-called "Treasury I"), which proposes, among other things, the abolition of the favorable treatment of capital gains and the allowance of a partial deduction for dividends. See 1 OfFice of THE SECRETARY, U.S. DEPT. OF the Treasury, TaX Reform for Fairness, Simplicity, and Economic GROWTH, at xii-xiv (1984); 2 id. at 133-37, 178-88.

101 See Preliminary RePoRt, supra note 182 , at 1.

${ }^{402} 688$ F.2d 520 (7th Cir. 1982). For a discussion of the McDonald's case, see supra text accompanying notes 169-77.

${ }^{103}$ See Preliminary RePORT, supra note 182 , at 29-32.

404 See supra text accompanying notes 169-205.

${ }^{408}$ IRS Private Letter Ruling No. 7839060 (June 28, 1978) (available July 1, 1985, on WESTLAW, FTX-WD database).

${ }^{100}$ See Rev. Rul. 80-285, 1980-2 C.B. 119; Rev. Rul. 80-284, 1980-2 C.B. 117. Both rulings cite Gregory v. Helvering, 293 U.S. 465 (1935). Presumably, the Service will not become technically flawless in the administration of the tax law after the new proposals are adopted.

607293 U.S. 465 (1935).

408 See Rev. Rul. 80-285, 1980-2 C.B. 119, 119; Rev. Rul. 80-284, 1980-2 C.B.

$117,118$.

${ }^{609}$ See Preliminary Report, supra note 182, at 28. 
former the option is de facto. Indeed, as earlier discussion has demonstrated, the proposed rules would still operate as a largely de facto regime.

These criticisms point out the hazards of overhauling this area of the law, where the transactions are so complicated and require advance planning. The present system is at least a known quantity. If the historical discussion above proves nothing else, it shows that judicially and legislatively mandated changes in this area can give rise to complex ramifications that are difficult to anticipate. These considerations might be borne in mind by those who wish to embark upon yet another major change of this area of law. "Those who cannot remember the past are condemned to repeat it." 